\title{
Impact of ship emissions on the microphysical, optical and radiative properties of marine stratus: a case study
}

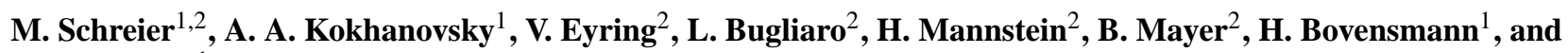 \\ J. P. Burrows ${ }^{1}$ \\ ${ }^{1}$ Institute for Environmental Physics (IUP), University of Bremen, Germany \\ ${ }^{2}$ Institut für Physik der Atmosphäre, DLR-Oberpfaffenhofen, Wessling, Germany
}

Received: 29 November 2005 - Published in Atmos. Chem. Phys. Discuss.: 3 February 2006

Revised: 30 August 2006 - Accepted: 18 October 2006 - Published: 30 October 2006

\begin{abstract}
Modifications of existing clouds by the exhaust of ships are well-known but inadequately quantified impacts, which could contribute to climate change. The perturbation of a cloud layer by ship-generated aerosol changes the cloud reflectivity and is identified by long curves in satellite images, known as ship tracks. As ship tracks indicate a pollution of a very clean marine environment and also affect the radiation budget below and above the cloud, it is important to investigate their radiative and climatic effects. Satellitedata from MODIS on Terra are used to examine a scene from 10 February 2003 where ship tracks were detected close to the North American West-Coast. The cloud optical and microphysical properties are derived using a semi-analytical retrieval technique combined with a look-up-table approach. An algorithm is presented to distinguish ship-track-pixels from the unperturbed cloud pixels in the scene and from this the optical properties of the former are compared to those of the latter. Within the ship tracks a significant change in the droplet number concentration, the effective radius and the optical thickness are found compared to the unaffected cloud. The resulting cloud properties are used to calculate the radiation budget below and above the cloud. Assuming a mean solar zenith angle of $63^{\circ}$ for the selected scene, the mean solar surface radiation below the ship track is decreased by $43.2 \mathrm{Wm}^{-2}$ and the mean reflectance at top of atmosphere (TOA) is increased by $40.8 \mathrm{Wm}^{-2}$. For the entire analyzed scene the ship emission decreases the solar radiation at the surface by $2.1 \mathrm{Wm}^{-2}$ and increases the backscattered solar radiation at TOA by $2.0 \mathrm{Wm}^{-2}$, whereas no significant effect on thermal radiation was detected.
\end{abstract}

Correspondence to: M. Schreier

(schreier@iup.physik.uni-bremen.de)

\section{Introduction}

Emissions by ships significantly contribute to the total budget of anthropogenic emissions. The exhaust gas emissions from ships include $\mathrm{CO}_{2}, \mathrm{NO}_{\mathrm{x}}, \mathrm{SO}_{\mathrm{x}}, \mathrm{CO}$, hydrocarbons, and particulate matter (Eyring et al., 2005a). Recently, satellite measurements of $\mathrm{NO}_{2}$ showed enhanced $\mathrm{NO}_{2}$ column amounts along major international shipping routes (Richter et al., 2004; Beirle et al., 2004). Ship emissions are released into the marine boundary layer and change the chemical composition of the atmosphere (Lawrence et al., 1999; Kasibhatla et al., 2000; Davis et al., 2001; Endresen et al., 2003) and climate (Capaldo et al., 1999; Endresen et al., 2003). The average sulphur fuel content of today's worldmerchant shipping fleet is $2.4 \%$ that results in a large amount of $\mathrm{SO}_{2}$ and particulate matter emissions (EPA, 2000). International maritime conventions do not regulate the sulphur content of fuel for shipping. However, there are regional and local emission legislations, for $\mathrm{NO}_{\mathrm{x}}$ but also for $\mathrm{SO}_{\mathrm{x}}$ and particulate matter (e.g., Entec, 2002; World Bunkering, 2004). During the last 50 years, the world's ocean-going fleet and the ships' total fuel consumption have increased considerably. Further increase of fuel consumption and emissions is expected in the future related to an increase in economic growth and sea borne trade (Eyring et al., 2005a, b). Ship emissions have been recognized as a growing problem by both policy makers and scientists (Corbett, 2003).

In addition to the impact on tropospheric chemistry, particle emissions from ships also change the physical properties of low clouds. This is the so-called indirect aerosol-effect, which has been observed in satellite data in many studies (e.g., Conover, 1966; Twomey et al., 1968; Radke et al., 1989). Natural aerosol in a maritime environment consists of a small amount of particles mainly composed of sea salt with diameters greater than $1 \mu \mathrm{m}$ (O'Dowd et al., 1997, 2004) and sulphate particles with diameters less than $1 \mu \mathrm{m}$ (McInnes et

Published by Copernicus GmbH on behalf of the European Geosciences Union. 
al., 1996). The low number of particles results in small optical thickness (Christopher and Zhang, 2002) and a small amount of aerosol available for cloud condensation. This limited number of cloud condensation nuclei is reflected in larger droplets and a smaller droplet number concentration in low-level stratiform clouds over the ocean compared to continental clouds (Miles et al., 2000). If additional aerosols are injected, the changes of the aerosol concentration and amount result in a change in the droplet number concentration within the cloud (Facchini et al., 1999), depending on the solubility and size of the injected aerosol particles. Particles and their precursors from ship emissions are able to act as cloud condensation nuclei $(\mathrm{CCN})$ in the water-vapour saturated environment of the maritime cloud or can change the surface tension due to the solubility. Which particulate matter of ship emissions is able to act as $\mathrm{CCN}$ is not entirely clarified, but especially the high sulphur content of the fuel may be an important factor for the modification of clouds, because the resulting $\mathrm{SO}_{\mathrm{x}}$ is able to act as CCN (Seinfeld and Pandis, 1997). Amount and size of these particles depends on the fuel and also the kind of combustion, but can possibly result in a higher droplet concentration (Twomey et al., 1968; Twomey, 1974) and consequently in a change of reflectivity of the maritime cloud.

Measurements in the Monterey Ship Track Experiment confirm this hypothesis (Durkee et al., 2000a). In the plumes, Hobbs et al. (2000) observed an increased amount of those particles which can act as CCNs in a supersaturated environment as well as the related increase in the cloud droplet concentration and the decrease in the cloud effective radius. Slight changes in the particle size distribution were reported by Öström et al. (2000). On the other hand, there was no evidence for the influence of sea salt particles (Durkee et al., 2000b) from the wake of the ship on the clouds and also no significant influence of heat and moisture from the ship stack (Hobbs et al., 2000). So, these measurements confirm the role of emitted particles as CCNs and especially the importance of $\mathrm{SO}_{\mathrm{x}}$.

Modifications of clouds by aerosols result in a significantly higher droplet concentration. This leads to an increased scattering, resulting in larger reflectances. This increased reflectance however, might be partially reduced due to the presence of highly absorbing particles (e.g. soot) in the plume exhaust. The increased reflectivity is even higher in the near infrared, because here, the ratio of absorption to scattering is strongly depending on the droplet size (Coakley et al., 1987; Kokhanovsky et al., 2004a).

In this study the modification of clouds and the influence of the ship exhaust on the radiation budget of a given scene are examined. Satellite data are used to retrieve cloud properties and their modifications due to ship emissions. Section 2 gives an overview of the selected satellite scene. Section 3 explains the approach for extracting the polluted (ship track) pixels and the algorithms to analyze microphysical and optical properties of the cloud. They are based on the semi-analytical cloud retrieval algorithm SACURA (Kokhanovsky et al., 2003) combined with look-up-tables for thin clouds calculated with the libRadtran radiative transfer package (Mayer and Kylling, 2005). The work concentrates on low clouds because only those are directly affected by ship emissions. The section also addresses how foam and turbulent waves caused in the ship wake may affect the reflectances and hence the extraction of ship tracks. The last part of this section describes calculations to determine the impact on the radiation budget.

The results of this study are presented in Sect. 4. The cloud mask separating ship-track-pixels and no-ship-track-pixels is shown in Sect. 4.1. Changes in the effective radius, optical thickness and droplet number concentration due to the exhaust plume are presented in Sect. 4.2. The resulting optical parameters obtained from the image analysis are used in Sect. 4.3 to calculate the radiation below and above the cloud and to estimate the influence of the modified clouds on the radiation close to the surface and also at the top of the atmosphere (TOA).

\section{Selected ship track scene}

For our analysis a particular and adequate satellite scene from Terra-MODIS (King et al., 1995) was selected using a resolution of $1 \mathrm{~km}$. The scene from 10th February 2003 , close to the West Coast of North America $\left(153^{\circ} \mathrm{W}\right.$ to $120^{\circ} \mathrm{W}$ and $40^{\circ} \mathrm{N}$ to $60^{\circ} \mathrm{N}$ ), exhibits a number of anomalous cloud lines in the stratiform clouds over the ocean. Figure 1 shows the reflectance in MODIS-data for channel 2 $(0.85 \mu \mathrm{m})$ and Fig. 2 the reflectance for channel $7(2.13 \mu \mathrm{m})$. These two channels are also used for the ship track detection. As explained above, the curves are more pronounced in the $2.13 \mu \mathrm{m}$-channel. The time of the satellite overpass is 20:25 UTC (11:25 local time), the solar zenith angle ranges between $55^{\circ}$ and $79^{\circ}$, depending on the location in the image. The observed type of clouds is typical for this region in the Northern Pacific (Norris, 1998a, b; Whang et al., 2000).

The scene contains the Northern Pacific and on the eastern edge, the American west coast is visible. Large ports like Vancouver and Seattle (see Fig. 1) are located on this coastline. A comparison with $1 \times 1$ degree vessel traffic density for the year 2000 (Endresen et al., 2003) for the area (Fig. 3) shows high density of ship traffic for the domain of the satellite scene. Any impact of air traffic is eliminated by taking into account the brightness temperature of the clouds, using the MODIS atmospheric window channel $31(11 \mu \mathrm{m}$, Fig. 4). The temperatures indicate low warm clouds for the anomalous cloud lines and therefore the impact of aircraft emissions is negligible. Meteorological conditions taken from ECMWF reanalysis data (ERA-40-project, Simmons and Gibson, 2001) for a geopotential height of $700 \mathrm{~m}$ above the ocean show a high pressure field over the northern Pacific with an anticyclonic wind field (Fig. 5). The curves 


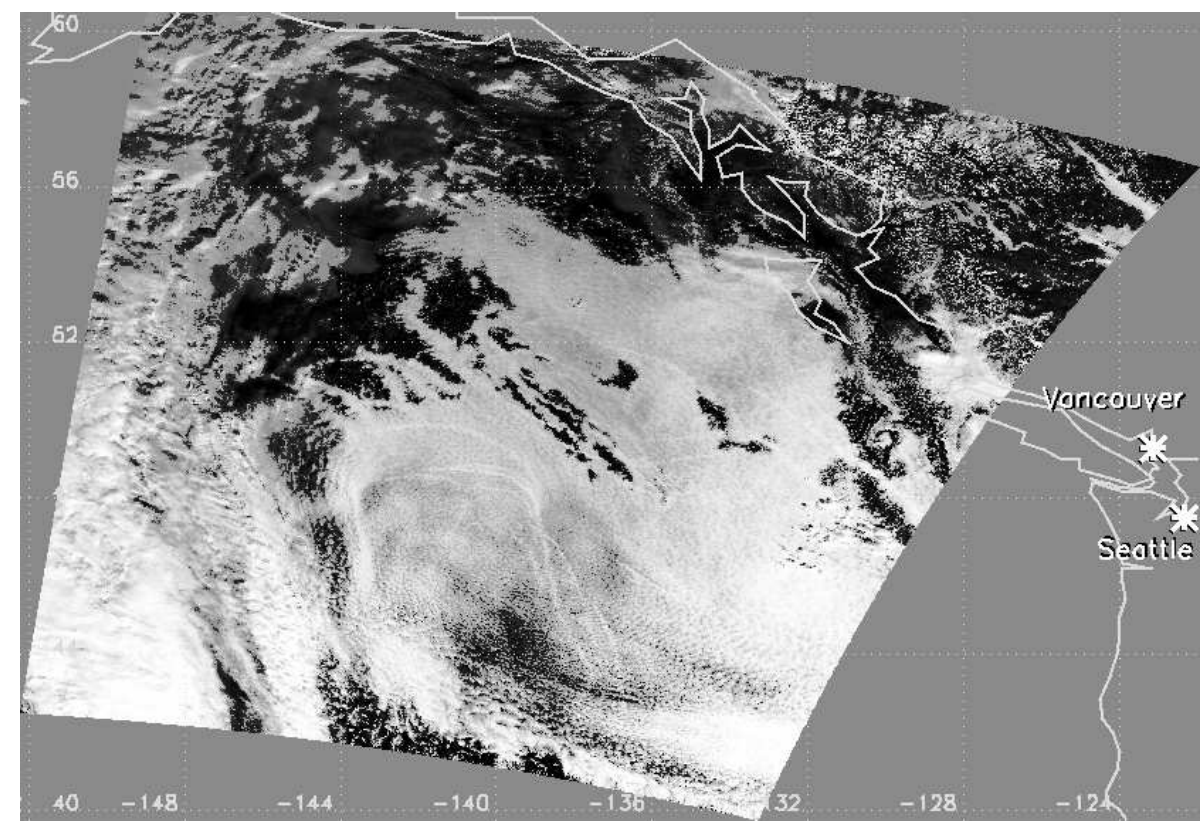

Fig. 1. Reflectance in channel $2(0.85 \mu \mathrm{m})$, Terra-MODIS, 10 February 2003 , from $153^{\circ}$ to $120^{\circ}$ west and $40^{\circ}$ to $60^{\circ}$ north .

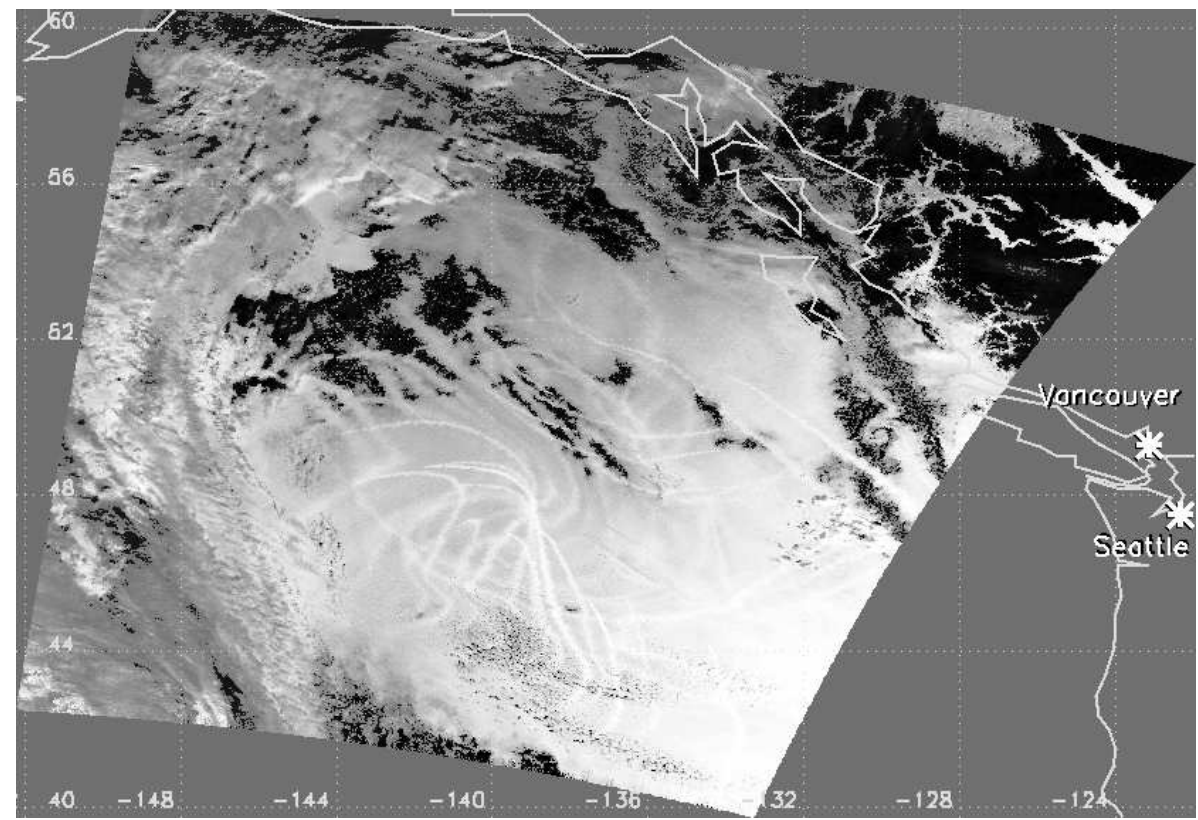

Fig. 2. Same as Fig. 1, but for $2.13 \mu \mathrm{m}$-channel.

are consistent with ship-tracks being formed by ship-traffic coming from or going to the great harbours of the West coast of North America being turned by the wind field. In conclusion it is very unlikely that this anomalous cloud lines have a source other than ship traffic emissions.

\section{Methods}

An automated algorithm to detect ship tracks in this scene has been developed in order to study how ship emissions modify clouds. Figure 6 shows a flow diagram of the ship track algorithm. The algorithm distinguishes between ship-track-pixels and no-ship-track-pixels, that is, polluted and unpolluted pixels. In addition, optical and physical properties of the low 


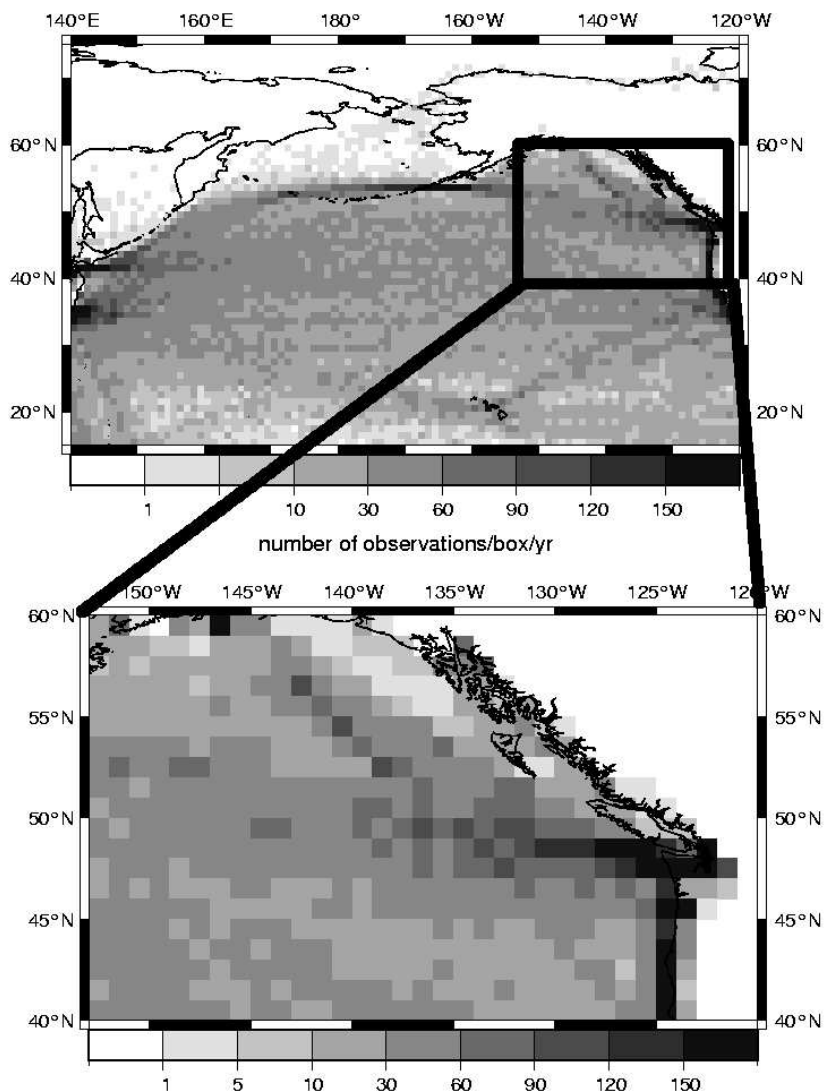

Fig. 3. Vessel traffic density of the total fleet for the year 2000 between $140^{\circ} \mathrm{E}$ to $120^{\circ} \mathrm{W}$ and $15^{\circ} \mathrm{N}$ to $75^{\circ} \mathrm{N}$. Data are taken from Endresen et al. (2003).

clouds are calculated and the derived optical properties are used to estimate the influence on the radiation budget.

\subsection{Ship track mask algorithm}

The upper part of the flow diagram in Fig. 6 shows the criteria that are used to identify ship-track-pixels. Sea pixels are first separated from land pixels by means of a land-seamask. Then a filter is applied to extract only those cloudy pixels, which are susceptible for the exhaust of ships. To determine a threshold for cloudy pixels, a histogram analysis of the reflectance was performed. For a pixel to be classified as cloudy, its reflectance at $0.65 \mu \mathrm{m}$ (Channel 1) has to be higher than $\mathrm{R}_{\text {threshhold }}=0.1$. For a pixel to be classified as low cloud, a temperature threshold was used. Durkee et al. (2000b) present measurements of the height of low stratiform clouds which are modified by ship emissions. The cloud top height never exceeded $1500 \mathrm{~m}$ in these measurements. Taking into account the temperature of the ocean and a lapse rate for a wet-adiabatic environment like the maritime boundary layer, the cloud top height can be estimated from the brightness temperature in channel $31(11 \mu \mathrm{m})$. To separate low cloud pixels from high cloud pixels the temperature difference $\Delta \mathrm{T}$ between the sea surface temperature $\left(\mathrm{T}_{\text {ocean }}\right)$ and the temperature of the cloudy pixels had to be less than $10.5 \mathrm{~K}$. The sea surface temperature $\mathrm{T}_{\text {ocean }}$ was derived from nearby cloud free pixels, while $\Delta \mathrm{T}$ has been calculated assuming a wet-adiabatic lapse rate of $0.7 \mathrm{~K} / 100 \mathrm{~m}$ for the maritime boundary layer and a maximum top altitude of $1500 \mathrm{~m}$. The temperature criterion also excludes the detection of aircraft contrails, as the algorithm only detects warm clouds. The remaining cloud covered pixels were classified as lowcloud-pixels.

Finally, pattern recognition, in particular Canny-Edgefiltering, was used in order to identify changes in the cloud reflectance, which indicate ship tracks. Enhancement of the edges was achieved by dividing the values of the satellite data from channel $2(0.85 \mu \mathrm{m})$ and channel $7(2.13 \mu \mathrm{m})$. Channel 7 is a good indicator for cloud modifications and therefore ship tracks, because the reflectivity strongly depends on the ratio of absorption to scattering in the near infrared, which can be seen in Fig. 2. Channel 2 helps to increase contrast for pixels with increased scattering. Using both channels, the contrast for pixels with a significant influence on the radiation, is increased.

The first step, Canny-Edge-filtering, does not distinguish between ship-track-pixels and natural cloud edges. To further select the ship track relevant pixels automatically the following criteria were applied in addition:

- Width of ship track: The number of pixels between two edge-pixels should not exceed a threshold, chosen for narrow curves;

- Ratio of inside/outside-pixel: The length and width of connected pixel-clusters should not exceed a threshold;

- Ratio of length/width: The number of neighbouring and connected pixels in an area should not exceed a threshold.

The thresholds were optimized manually to minimize the false detection of clouds, by excluding edges that were obviously not ship tracks but natural clouds, e.g. for this scene we found an optimum at a width of 10 pixels between the edges. The result of the ship track mask algorithm described above is first a differentiation of the low-cloud-pixels from high cloud-pixels and second a separation of low-cloud-pixels into the two categories ship-track-pixels and no-ship-track-pixels.

In Sect. 4 the sensitivity of the different parameters of the cloud mask are described. To minimize the false detection of ship track-pixels, the algorithm was optimized empirically to identify ship-track-pixels in the scenes, which contribute significantly to the radiative forcing. These are defined as radiatively relevant ship-track-pixels.

\subsection{Impact of uncertainties due to surface reflectance}

Ships create wakes marked by foam with increased reflectivity. For thin, semi-transparent clouds this increased 


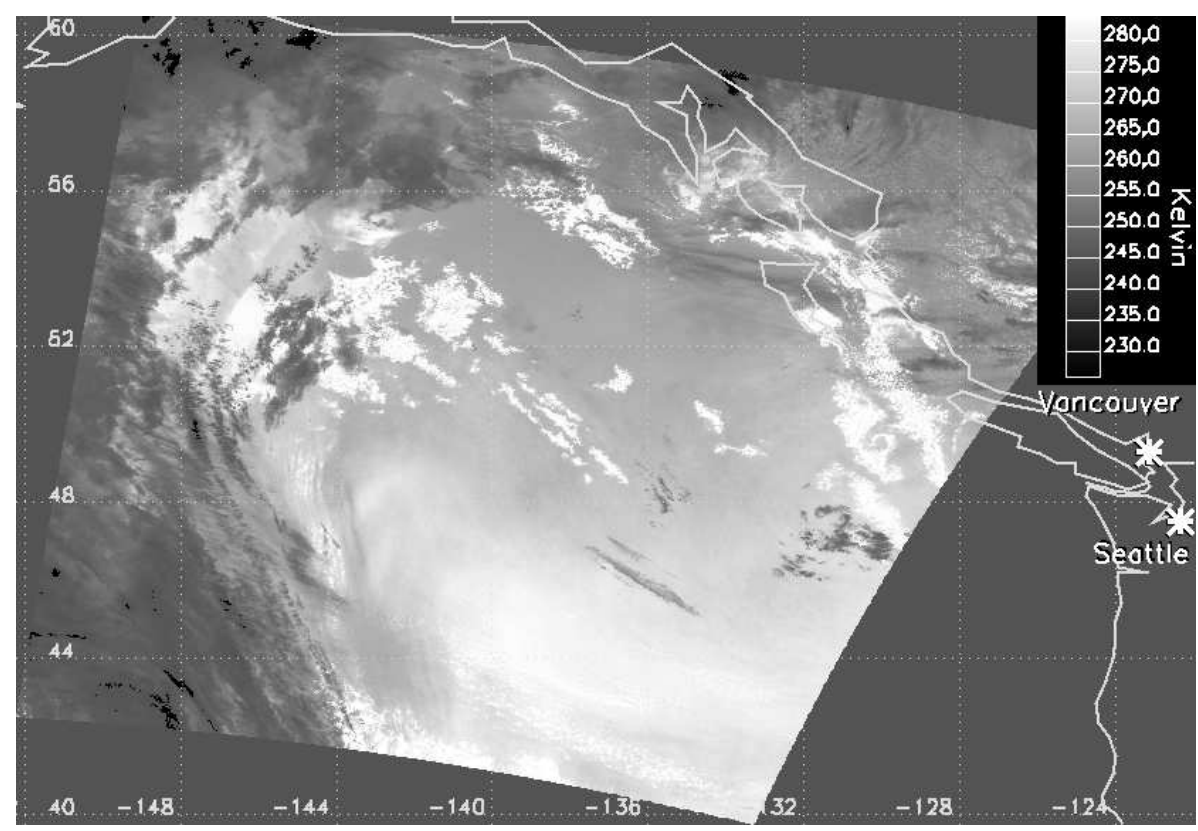

Fig. 4. Temperature of the selected scene in Kelvin, derived from satellite data $(11 \mu \mathrm{m})$.

reflectance might be misinterpreted as a modification of the cloud parameters. To analyse reflectance changes produced by the wake of the ship, sensitivity simulations have been carried out with libRadtran (Mayer and Kylling, 2005) at $0.85 \mu \mathrm{m}, 1.64 \mu \mathrm{m}$, and $2.13 \mu \mathrm{m}$.

The sensitivity simulations were calculated using a solar zenith angle of $60^{\circ}$, a satellite zenith angle of $10^{\circ}$, a relative azimuth angle of $45^{\circ}$ and cloud optical properties representative for the conditions of the examined satellite image (see Sect. 4.2.). A first calculation (SIM1) was designed to simulate a "normal" cloud over an almost black Lambertian ocean surface (spectral reflectances of 0.03 at $0.85 \mu \mathrm{m}$ and 0.0 at $1.64 \mu \mathrm{m}$ and $2.13 \mu \mathrm{m}$ ), using an effective radius of $13.2 \mu \mathrm{m}$ and a optical thickness of 20.7 for a no-ship-track pixel. A second calculation (SIM2) was designed to simulate an hypothetical ship wake filling the whole pixel, and used an ocean surface with spectral reflectances of 0.6 for $0.85 \mu \mathrm{m}$ and 0.3 for $1.64 \mu \mathrm{m}$ and 0.1 for $2.13 \mu \mathrm{m}$ (Kokhanovsky, 2004b). In SIM2 the same cloud optical parameters as in SIM1 have been used. The third calculation (SIM3) is similar to SIM1, but uses cloud optical parameters typical for a ship track rather than for an unpolluted cloud: In SIM3 an effective radius of $10.1 \mu \mathrm{m}$ and a cloud optical thickness of 34.6 were used.

Figure 7a shows the calculated differences in reflection between SIM1 and SIM2 and betweeen SIM1 and SIM3. The change in reflectivity in the visible wavelength channel $(0.85 \mu \mathrm{m})$ is almost the same for changes in surface albedo. In this case, changes in reflectivity due to ship tracks could not be distinguished from changes in surface reflectance, e.g. due to foam in a wake. However, for the longer wavelength

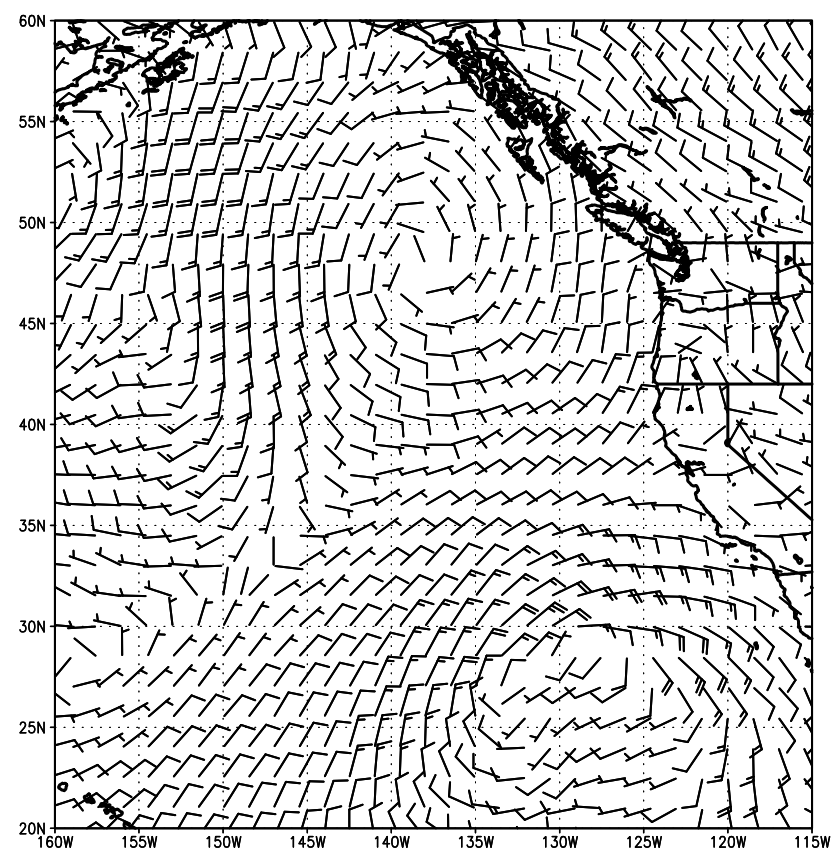

Fig. 5. Wind field from ECMWF reanalysis data on 10 February 2003 at 18:00 UTC.

channels $(1.64 \mu \mathrm{m}$ and $2.13 \mu \mathrm{m})$ the change in reflectivity between ship track and foam is obvious.

Adding the information of a wavelength in the near infrared reduces the possibility to interpret changes in surface albedo due to foam as changes in cloud optical parameters. Calculations at $2.13 \mu \mathrm{m}$ showed the best signal-to-noise ratio 


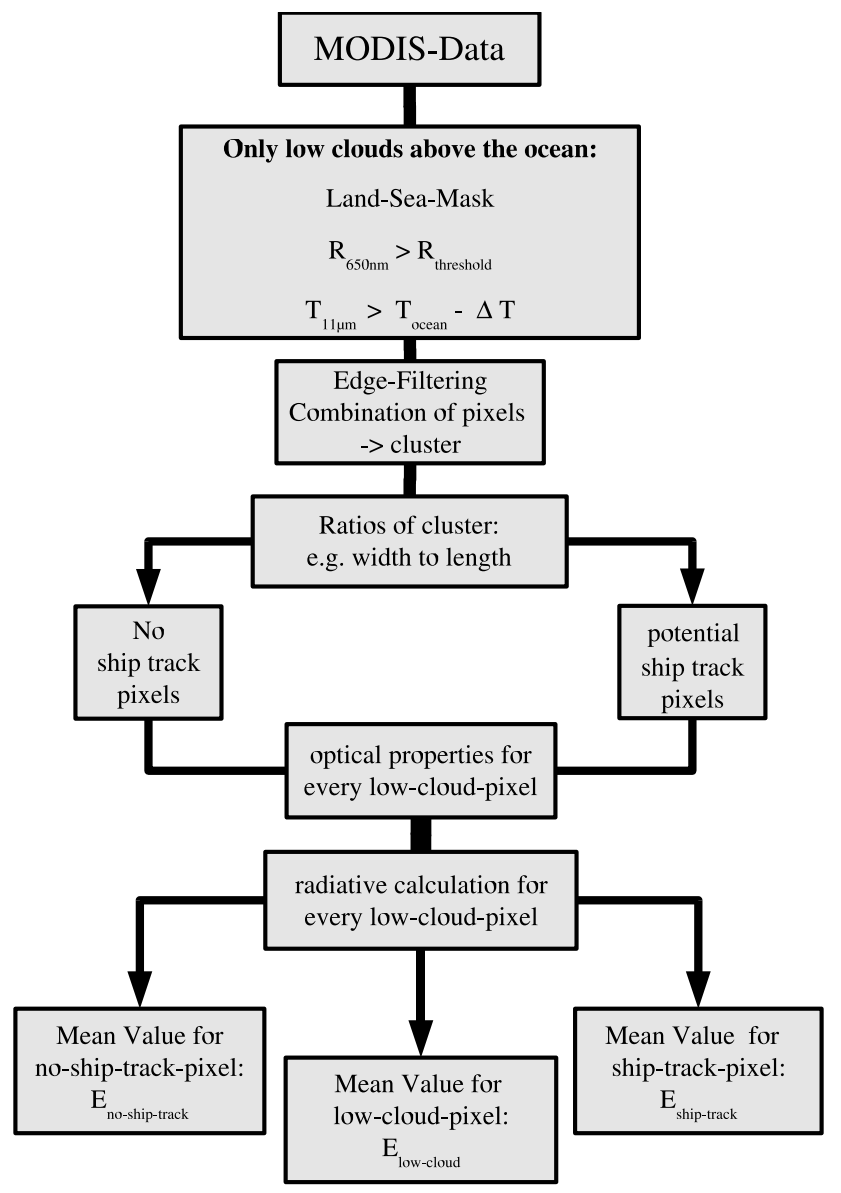

Fig. 6. Flow chart of the ship-track-algorithm that has been used in this study to identify ship tracks and calculate microphysical, optical and radiative properties.

such that the use of this channel is particulary helpful for ship track detection.

The same three sensitivity calculations were repeated for a thinner cloud with a cloud optical thickness of 5.0 and an effective radius of $13.2 \mu \mathrm{m}$ for "normal" optical cloud parameters and a cloud optical thickness of 10.0 and an effective radius of 10.1 for a ship track cloud. This is shown with same albedo assumptions as before in Fig. 7b. Here, the ocean albedo has a remaining influence also on $2.13 \mu \mathrm{m}$ that could be misinterpreted as a change in cloud contrast by the shiptrack-mask-algorithm.

To exclude possible misdetection, in addition a smaller scene has been selected (hereafter: "smaller selected scene"), where the cloud optical thickness of the unpolluted clouds near the ship tracks is very high. The optical thickness in this subset is 10 to 30 in the no-ship-track-clouds. Therefore, effects of changes in contrast due to foam or turbulence for $2.13 \mu \mathrm{m}$ are in any case negligible for the selected area. Also the amount of cloud edges and fractional cloud cover is reduced in this smaller selected scene. Therefore, the detection of ship tracks in the smaller selected scene is more reliable than the entire scene.

\subsection{Cloud properties retrieval}

We developed our own algorithm in order to be able to apply the retrieval to different satellite instruments. This new algorithm combines the semi-analytical cloud retrieval algorithm SACURA (Kokhanovsky et al., 2003) and look-uptables (LUTs) for thin clouds calculated with the libRadtran radiative transfer package (Mayer and Kylling, 2005). An advantage of the algorithm is that it can be applied to different satellite instruments with channels in the near infrared (e.g. Terra-MODIS, AATSR).

The optical and microphysical parameters of the cloud were derived from MODIS channel $2(0.85 \mu \mathrm{m})$ and channel $6(1.64 \mu \mathrm{m}) .1 .64 \mu \mathrm{m}$ was selected because the smaller absorption of liquid water enables more accurate results for the SACURA-retrieval. The two cloud retrieval algorithms SACURA and LUTs - are different, but both derive the cloud optical thickness and also the effective radius $r_{\text {eff }}$, defined by the ratio of the third to second moment of the particle size distribution and therefore indicating a change of the ratio of volume to surface in the particle size distribution.

SACURA is a semi-analytical approach based on the fact that the probability of photon absorption by droplets in the visible and near-infrared spectral regions is low (Kokhanovsky et al., 2003). The technique relies upon asymptotic equations of the radiative transfer theory valid for the values of the single scattering albedo $\omega_{0}$ close to one, which allows a much faster calculation of reflectances than a numerical solution of the radiative transfer equation. SACURA was compared to other cloud retrieval algorithms (Nauss et al., 2005) and the retrieved values agreed well. SACURA calculates the effective radius from the observed reflectances and uses this value to derive optical thickness and liquid water path, assuming a vertically homogeneous cloud. The ocean surface reflectance for SACURA was assumed to be 0.03 for $0.85 \mu \mathrm{m}$ and 0.0 for $1.64 \mu \mathrm{m}$. The advantages of SACURA are its speed and high accuracy and also an interpolation is not necessary. A disadvantage of SACURA is the increasing error for decreasing cloud optical thickness.

Therefore, for clouds with an optical thickness of 5 and below, a look-up-table approach and an interpolation is used, to have a wider range of applicability in terms of the cloud optical thickness. The look-up-table (LUT) is calculated using the radiative transfer code libRadtran (Mayer and Kylling, 2005), assuming mid-latitude standard atmosphere and a cloud top height of $1000 \mathrm{~m}$. The scattering properties of the cloud are based on Mie-calculations and the assumed surface reflectance was the same as for SACURA. Reflectances were calculated for a wide range of optical thicknesses and effective radii. A best-fit method is used to find the cloud optical thickness and $r_{\text {eff }}$ for the observed reflectances. 

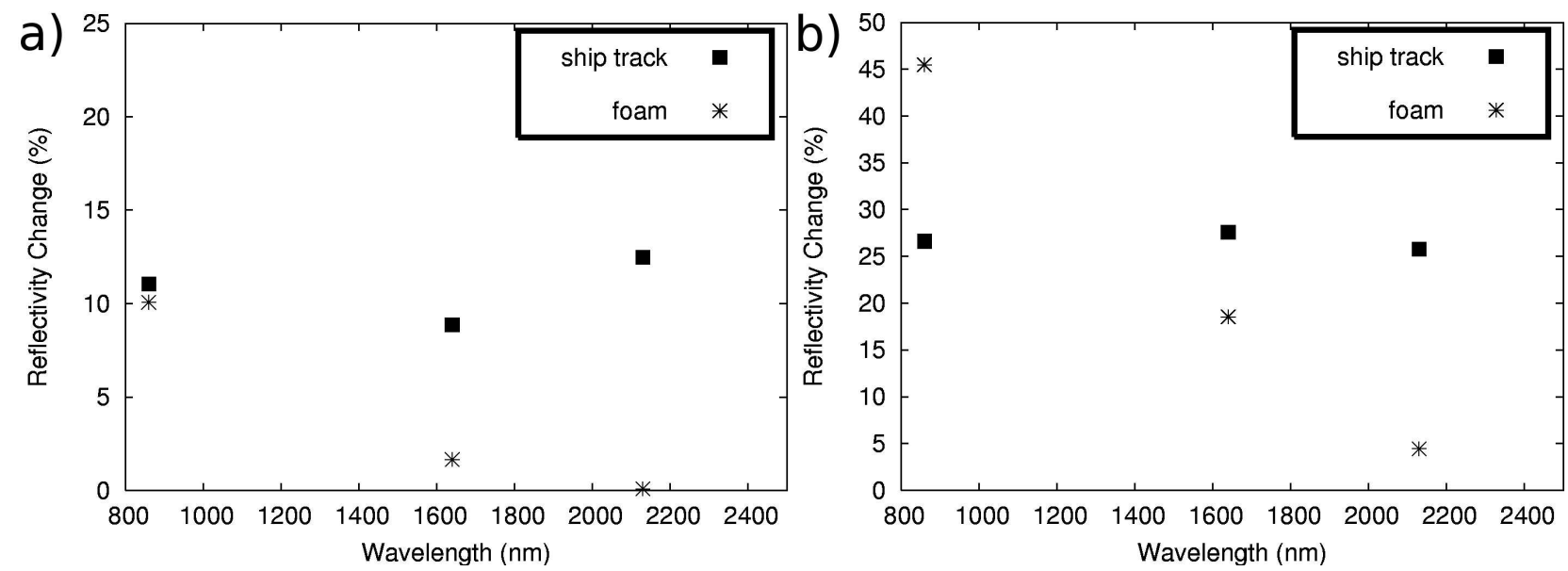

Fig. 7. Changes in simulated reflectivity (TOA) due to changes in surface reflection by foam or changes of cloud optical properties. Panel (a) shows a thick cloud (no ship track: 20.7 for optical thickness and $13.2 \mu \mathrm{m}$ for effective radius, ship track : 34.6 and $10.1 \mu \mathrm{m}$ ), panel (b) shows a thin cloud (no ship track: 5.0 and $13.2 \mu \mathrm{m}$, ship track: 10.0 and $10.1 \mu \mathrm{m}$ ).

The columnar droplet number concentration for both retrievals is calculated via effective radius and cloud optical thickness by assuming a gamma droplet size distribution with a coefficient of variance of 0.37 as proposed by Deirmendjian (1969). Calculations of droplets per volume (N) were performed using a hypothetical vertical homogeneous cloud of a thickness $500 \mathrm{~m}$, which is a reasonable value for low marine stratiform clouds (Cahalan et al., 1994; Han et al., 1998). This calculation does not influence the relative changes and resulting values per volume are useful for comparing with measured cloud droplet concentrations, e.g. Miles (2000).

Threshold criterion for calculations with either SACURA or LUT was the reflectance of channel $2(0.85 \mu \mathrm{m})$, using a value, which approximately fits to the cloud optical thickness around 5. The cloud optical thickness is calculated at $0.55 \mu \mathrm{m}$ for the LUT and $0.85 \mu \mathrm{m}$ for SACURA, but cloud optical thickness is approximately wavelength-independent in this region. Calculations with both retrievals around $+/-0.1$ of the reflectance-selection criteria near the threshold showed a correlation factor of 0.73 for the optical thickness with a mean relative deviation of $11.3 \%$, and 0.91 for the effective radius, with a mean relative deviation of $6.7 \%$. The differences are within the uncertainty of the theoretical model, e.g. the assumption of an unpolluted vertically and horizontally homogeneous cloud within a pixel.

\subsection{Estimating the impact on the radiation field}

The derived optical parameters were used to estimate changes in solar radiation for the areas below and above the cloud as well as the thermal outgoing radiation by radiative transfer calculations. Optical thickness and the effective radius have been applied to create look-up-tables for the solar flux via the radiative transfer code libRadtran (Mayer and Kylling, 2005), by using the built in k-distribution by Kato et al. (1999) to calculate integrated solar irradiance with the solver disort2 (Stamnes et al., 1988) for the wavelength range of $0.24 \mu \mathrm{m}$ to $4.6 \mu \mathrm{m}$. The down-welling irradiance at the surface and the up-welling flux at TOA were calculated for the mid-latitude winter atmosphere (AFGL-TR-860110, Anderson et al., 1986). The different distributions of cloud optical properties were considered by using these lookup-tables to calculate the solar flux for every pixel and taking into account the local solar zenith angle. The cloud top height was chosen to be $1000 \mathrm{~m}$ and the cloud-bottom height was $500 \mathrm{~m}$. The optical properties of the clouds were calculated according to Mie theory. The mean values for all low-cloud-pixels, ship-track-pixels and no-track-pixels were determined (results see Sect. 4.3), to estimate the impact of ship tracks on both, the solar radiation at the surface and the backscattered radiation at TOA.

In a similar manner to the calculations described above, changes in thermal radiation resulting from changes in cloud optical properties were calculated $(0.2 \mu \mathrm{m}$ to $100 \mu \mathrm{m})$, using the correlated-k distribution by Fu and Liou (1992). Estimation of exact cloud top height is uncertain for these clouds, but possible influence on cloud top height due to aerosol was included. The thermal radiation of every pixel was calculated by taking into account the actual cloud top height. This quantity was determined by matching the measured brightness temperatures at $11 \mu \mathrm{m}$ (Fig. 11) to an appropriate temperature profile by assuming a lapse rate of $0.7 \mathrm{~K} / 100 \mathrm{~m}$. 

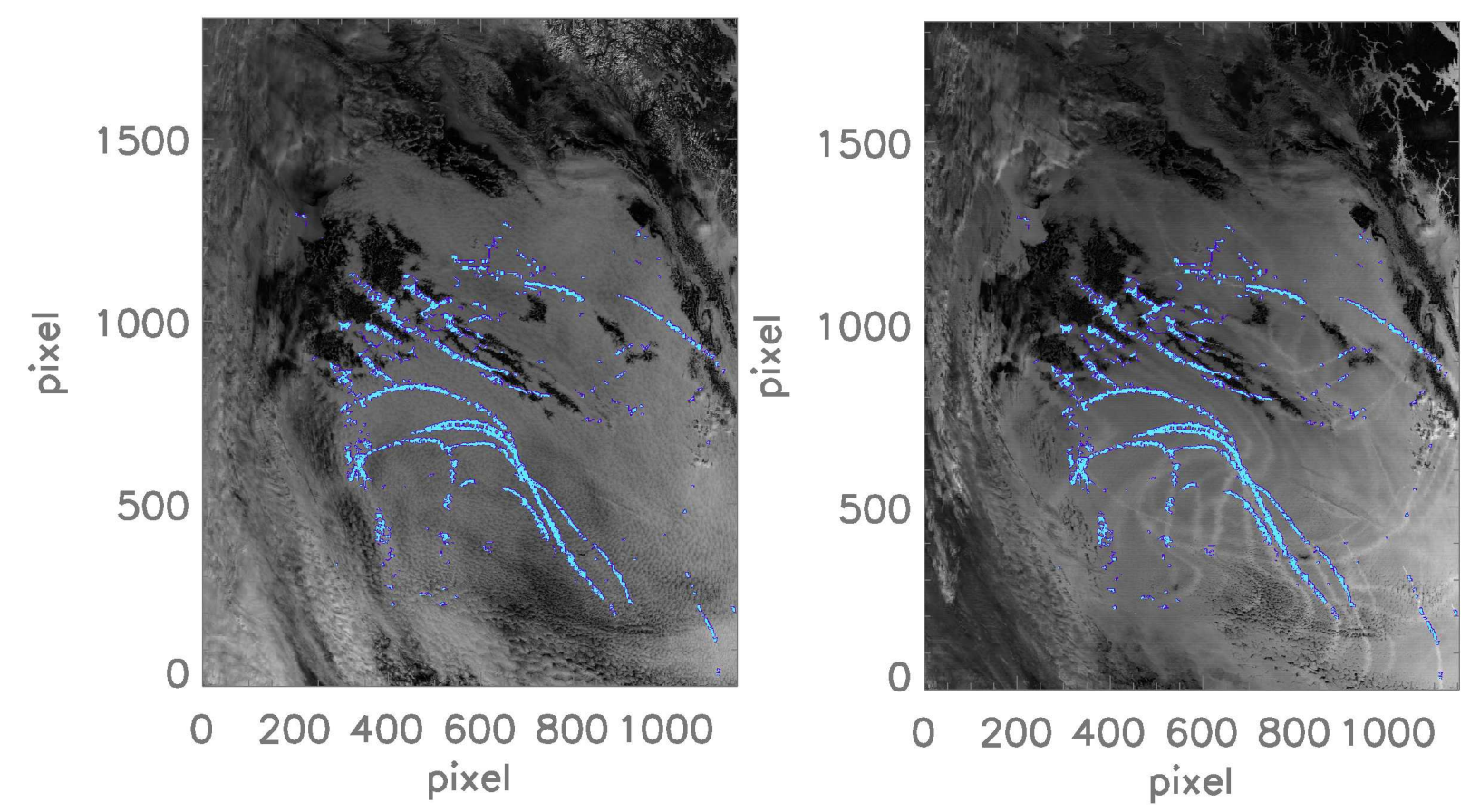

Fig. 8. Results of the ship track mask, plotted over the satellite data shown in Figs. 1 and 2. Ship-track-pixels are indicated in blue.

Table 1. Sensitivity analysis: Detected ship-track-pixels for variations of the cloud-mask-parameters, compared to the $6.7 \%$ detected shiptrack-pixels that are used for the examination.

\begin{tabular}{lcc}
\hline & Change of parameter $(\%)$ & Detected ship-track-pixels $(\%)$ \\
\hline Canny-Edge Parameter & $-10 / 10$ & $5.3 / 8.6$ \\
& $-50 / 50$ & $2.2 / 31.5$ \\
Width of ship track & $-10 / 10$ & $6.2 / 7.1$ \\
& $-50 / 50$ & $4.0 / 8.2$ \\
Ratio inside/outside-pixel & $-10 / 10$ & $6.6 / 6.8$ \\
& $-50 / 50$ & $6.6 . / 6.8$ \\
Ratio of length/width & $-10 / 10$ & $6.6 / 6.8$ \\
& $-50 / 50$ & $6.1 / 7.1$ \\
\hline
\end{tabular}

\section{Results}

\subsection{Detected ship tracks}

Figure 8 shows the resulting analysis of the particular scene derived from the ship track mask algorithm described in Sect. 3.1. The resulting ship-track-pixels are shown in blue together with the satellite data of Fig. 1 and 2. A small number of pixels marked as ship-track-pixels are not inside a ship track and almost a third of the ship tracks seem not to be detected. However, the ship tracks visible at the shorter wavelengths are almost all detected and those are the relevant pixels for the solar radiative budget. By using the combination of channels 7 and 2 only those ship-track-pixels are detected, which significantly change the backscattered radiation at top of atmosphere. For the whole scene, $6.7 \%$ of the low-cloudpixels were identified as ship-track-pixels and $93.3 \%$ as noship-track-pixels. For the smaller selected scene $8.6 \%$ shiptrack-pixels and $91.4 \%$ no-ship-track-pixels were identified by the algorithm.

To test the sensitivity of the algorithm on the cloud mask algorithm parameters, we have varied the parameters for Canny-Edge filtering, the width of the ship track, the ratio of inside and outside pixels as well as the ratio of length to width (see Sect. 3.1) by $+/-10 \%$ and $50 \%$. Table 1 shows the detected ship-track-pixels in percent of the entire scene for the different input parameters. Results are most sensitive to changes in the Canny-Edge parameter. A change of 
Table 2. Mean values of cloud parameters and standard deviation (STD) in parenthesis.

\begin{tabular}{lccc}
\hline & low-cloud-pixels & no-ship-track-pixels & ship-track-pixels \\
\hline All low-cloud-pixel & & & \\
effective radius $(\mu \mathrm{m})$ & $13.0(4.0)$ & $13.2(4.0)$ & $10.1(2.5)$ \\
optical thickness & $21.4(11.1)$ & $20.7(10.4)$ & $34.6(14.5)$ \\
droplet number $\left(\mathrm{cm}^{-3}\right)$ & $85(61.7)$ & $79(82.8)$ & $210(112.6)$ \\
& & & \\
Smaller selected scene & & $11.9(3.8)$ & $8.9(2.3)$ \\
effective radius $(\mu \mathrm{m})$ & $11.6(3.9)$ & $23.8(10.2)$ & $30.9(11.8)$ \\
optical thickness & $24.4(10.5)$ & $101(46)$ & $255(101)$ \\
droplet number $\left(\mathrm{cm}^{-3}\right)$ & $115(60)$ & & \\
\hline
\end{tabular}

Table 3. Changes in mean values of retrieved cloud optical properties by changes in cloud-mask-parameters.

\begin{tabular}{lccccccc}
\hline & ship & track & pixels & no ship & track & pixels & \\
\hline & $\begin{array}{c}\text { Change } \\
\text { of } \\
\text { param }(\%)\end{array}$ & $\begin{array}{c}\text { eff. } \\
\text { radius } \\
(\mu \mathrm{m})\end{array}$ & $\begin{array}{c}\text { opt. } \\
\text { thick. }\end{array}$ & $\begin{array}{c}\mathrm{N} \\
\left(\mathrm{cm}^{-3}\right)\end{array}$ & $\begin{array}{c}\text { eff. } \\
\text { radius } \\
(\mu \mathrm{m})\end{array}$ & $\begin{array}{c}\text { opt. } \\
\text { thick. }\end{array}$ & $\begin{array}{c}\mathrm{N} \\
\left(\mathrm{cm}^{-3}\right)\end{array}$ \\
\hline Canny-Edge Parameter & 10 & 10.3 & 34.2 & 198 & 13.0 & 20.9 & 81 \\
& 50 & 11.2 & 28.9 & 140 & 12.8 & 20.8 & 81 \\
Width of ship track & 10 & 10.0 & 34.4 & 215 & 13.1 & 20.8 & 80 \\
& 50 & 9.5 & 33.5 & 225 & 13.4 & 21.0 & 79 \\
Ratio of inside/outside & 10 & 10.0 & 34.5 & 212 & 13.1 & 20.7 & 80 \\
& 50 & 10.0 & 34.8 & 214 & 13.1 & 20.7 & 80 \\
Ratio of length/width & 10 & 10.0 & 34.5 & 212 & 13.1 & 20.7 & 80 \\
& 50 & 10.0 & 34.6 & 213 & 13.1 & 20.7 & 80 \\
\hline
\end{tabular}

$+/-10 \%$ results in a loss of $1.4 \%$ increase of $1.9 \%$, respectively. Results are also sensitive to the width of the ship track defined as the pixels from one edge to another. A value of 10 pixels was used as default in the algorithm. Changing this to $9 / 5$ pixels results in a decrease of $0.5 \% / 4 \%$, respectively. Increasing the value to 11 or 15 pixels results in an increase of $0.4 \%$ or $1.5 \%$. Results are not sensitive on the ratio of inside and outside pixels and the ratio of length to width.

\subsection{Microphysical and optical cloud properties}

The cloud retrieval algorithm (Sect. 3.3) was used to calculate optical and microphysical parameters of low clouds (Fig. 9). Ship emissions result in the decrease of the effective radius (Fig. 9a). The increase of the optical thickness is also significant (Fig. 9b). Obvious is a high increase in the droplet concentration (Fig. 9c) compared with the unpolluted cloud scene.

Figure 10 shows the smaller selected area to allow a more detailed analysis of the ship track characteristics. In this area no cloud-edges are included and also the solar zenith angle (SZA) varies between $60^{\circ}$ and $66^{\circ}$ so can be assumed as almost constant. In addition, the optical thickness of the no- ship-track clouds is mostly higher than 10 (see Sect. 3.2) and therefore changes in reflectivity due to foam can be excluded. A significant decrease of the effective radius from $12 \mu \mathrm{m}$ to $6 \mu \mathrm{m}$ is visible across the ship-track-pixels (Fig. 10a). The optical thickness of unpolluted clouds is about 20 to 30 and is increasing in the track up to 45 and higher (Fig. 10b). Also the change in the droplet number concentration from around $100 \mathrm{~cm}^{-3}$ up to $800 \mathrm{~cm}^{-3}$ is substantial (Fig. 10c).

Table 2 summarizes the mean values of the various parameters for the low-cloud-pixels, both for the entire area as well as for the selected area for ship-track-pixels and noship-track-pixels. The decrease in the effective radius from 13.2 to $10.1 \mu \mathrm{m}$ for the entire area and from 11.9 to $8.9 \mu \mathrm{m}$ for the smaller area is evident and also an increase in cloud optical thickness from 20.7 up to 34.6 for the entire area and from 23.8 up to 30.9 for the selected area is observed.

Table 3 provides an analysis of retrieved mean optical cloud properties (effective radius, optical depth and number concentration), if the cloud mask parameters are varied according to Table 1 . The mean optical parameters are only sensitive to the edge filtering (Canny-Edge-parameter) and the width of the ship track. 

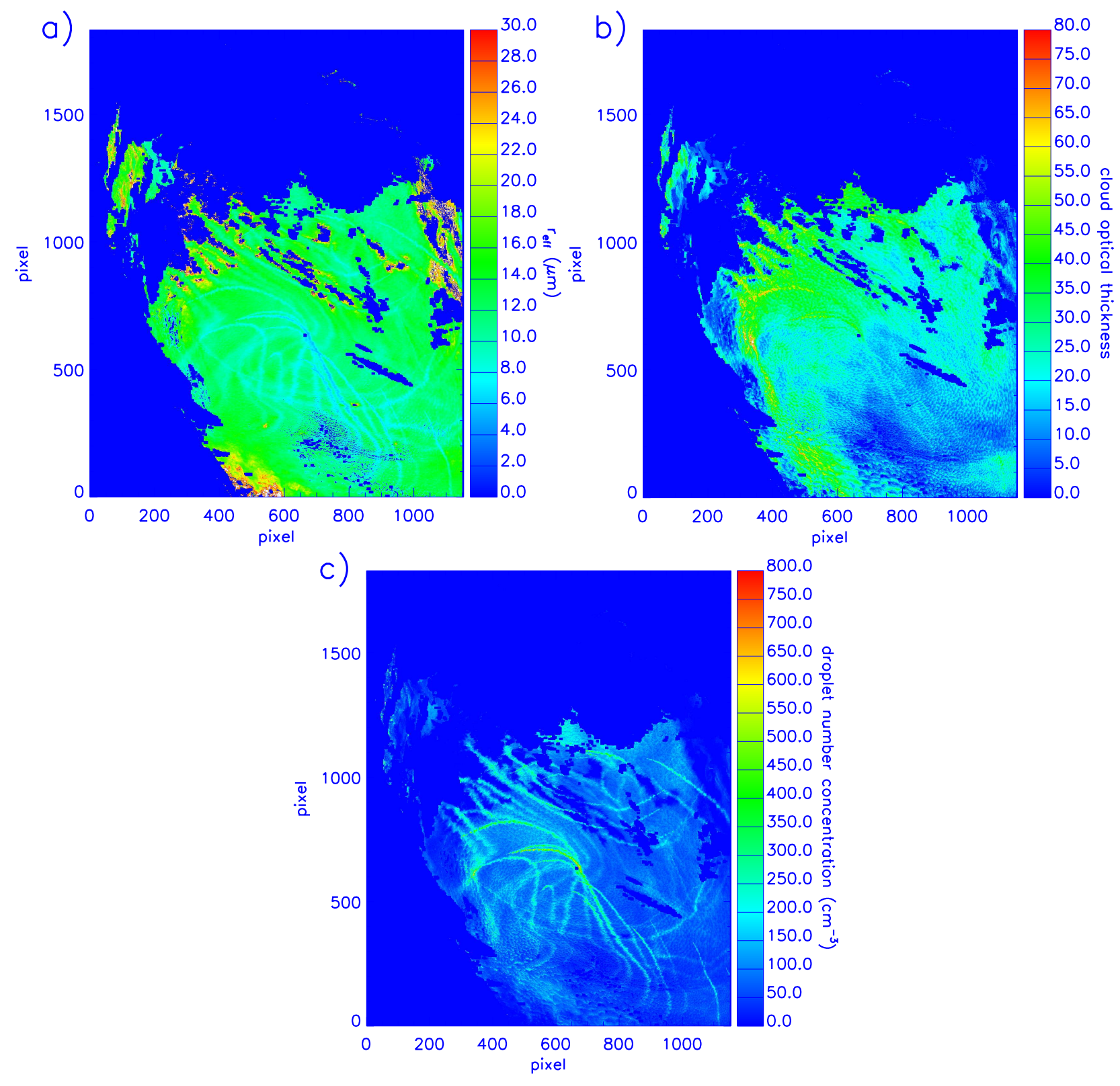

Fig. 9. Effective radius (a), cloud optical thickness (b) and concentration of particles $(\mathbf{c})\left(\mathrm{cm}^{-3}\right)$ derived from the MODIS channels 2 and 6 for the analysed scene.

To evaluate our results presented above, we compare the parameters cloud optical thickness and effective radius with the same parameters in freely available MODIS cloud standard product (King et al., 2003; Platnick et al., 2003). For the entire scene an effective radius of $13.2 \mu \mathrm{m}$ for the no-shiptrack-pixels and $10.6 \mu \mathrm{m}$ for the ship-track-pixels is calculated for the MODIS standard product. The optical thickness increases from 17.8 in no-ship-track pixels to 29.8 in ship-tracks-pixels. In the smaller selected scene, the effective radius decreases from no-ship-track-pixels $(11.7 \mu \mathrm{m})$ to ship-track-pixels $(8.6 \mu \mathrm{m})$ and the optical thickness increases from 17.6 to 23.3. Overall, the MODIS cloud standard product gives very similar results for the effective radius, whereas the optical thickness in our retrieval is slightly larger, which is consistent with Nauss et al. (2005).

Figure 11 shows the resulting statistical distributions of the parameters comparing no-ship-track-pixels and ship-trackpixels for all low-cloud-pixels (A, B, C) and for the smaller selected area $(\mathrm{a}, \mathrm{b}, \mathrm{c})$. If all low-cloud-pixels are considered (Fig. 11A), a change of the maximum of the effective 

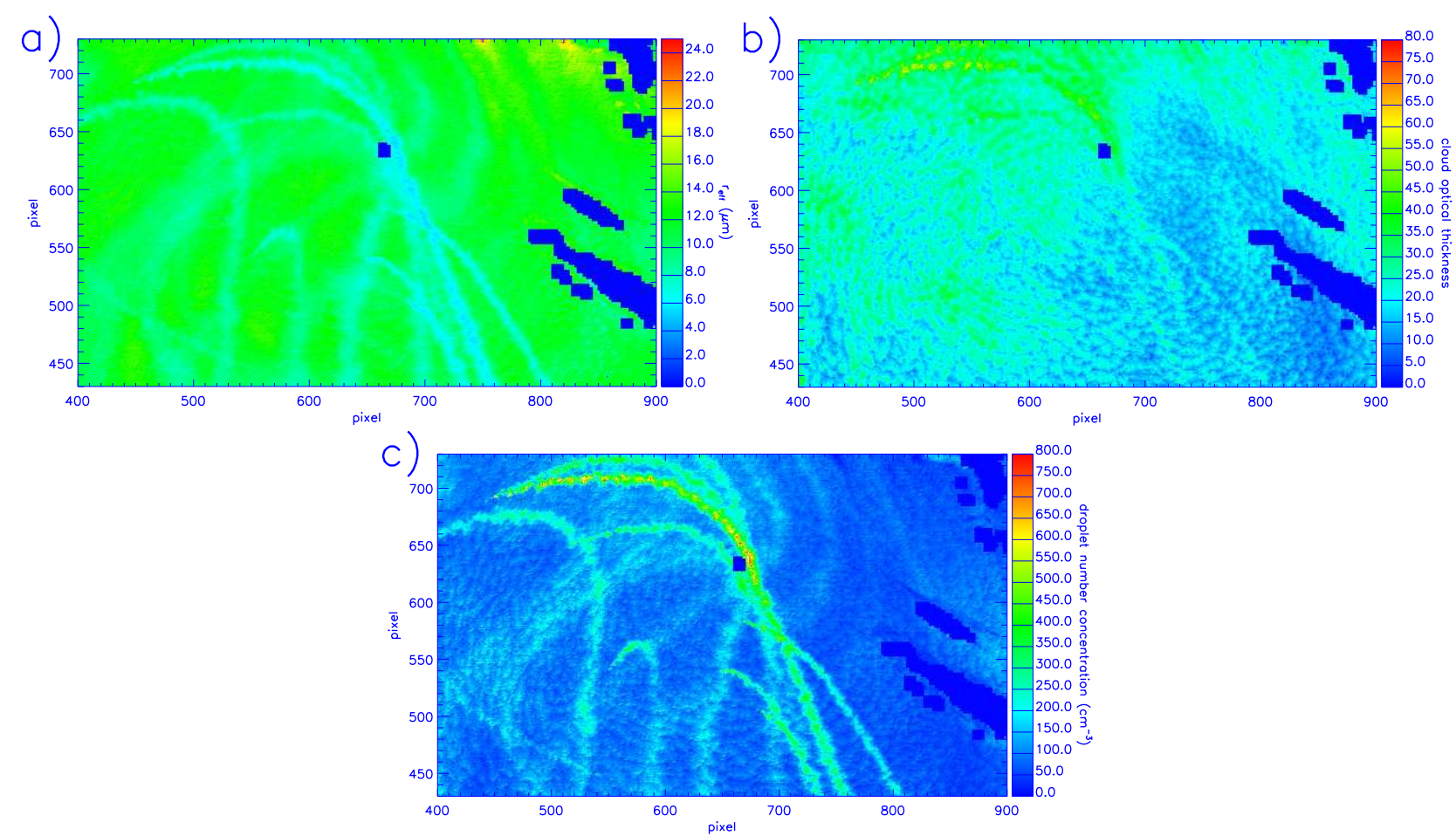

Fig. 10. Effective radius (a), cloud optical thickness (b), and droplet number concentration (c) derived from the MODIS channels 2 and 6 for the smaller selected area.

Table 4. Mean values of the transmitted solar flux at the surface and reflected radiation at the top of atmosphere, STD in parenthesis.

\begin{tabular}{|c|c|c|c|c|}
\hline & $\begin{array}{l}\text { low-cloud-pixels } \\
\text { E }_{\text {low-cloud }}\end{array}$ & $\begin{array}{l}\text { no-ship-track-pixels } \\
\text { Eno-ship-track }^{\text {noct }}\end{array}$ & $\begin{array}{l}\text { ship-track-pixels } \\
\text { E }_{\text {ship-track }}\end{array}$ & $\begin{array}{c}\text { difference } \\
\mathrm{E}_{\text {low-cloud }}-\mathrm{E}_{\text {no-ship}- \text { track }}\end{array}$ \\
\hline \multicolumn{5}{|l|}{ All low-cloud-pixel } \\
\hline Surface $\left(\mathrm{Wm}^{-2}\right)$ & $127.6(61.1)$ & $130.1(61.0)$ & $78.7(36.1)$ & -2.5 \\
\hline TOA $\left(\mathrm{Wm}^{-2}\right)$ & $336.2(55.9)$ & $335.4(56.9)$ & $353.5(26.2)$ & 0.9 \\
\hline \multicolumn{5}{|c|}{ Smaller selected scene } \\
\hline Surface $\left(\mathrm{Wm}^{-2}\right)$ & $113.4(28.3)$ & $115.5(27.5)$ & $92.6(27.6)$ & -2.1 \\
\hline TOA $\left(\mathrm{Wm}^{-2}\right)$ & $349.8(16.2)$ & $348.2(15.6)$ & $365.1(13.3)$ & 1.6 \\
\hline
\end{tabular}

radius towards smaller radii can be seen, whereas the distribution is changed towards higher values for the cloud optical thickness (Fig. 11B). The maximum of the droplet number distribution curve shows a significant shift of the maximum from $70 \mathrm{~cm}^{-3}$ to $160 \mathrm{~cm}^{-3}$ (Fig. 11C). Droplet numbers are higher than $500 \mathrm{~cm}^{-3}$, in contrast to the ones outside of the tracks. The distribution of the cloud optical thickness inside the tracks shows values again above 50 (Fig. 11b), which do not appear in the distribution of the outside pixels. The shiptrack-pixels of the selected area also show a narrower distribution for the effective radius and the cloud optical thickness confirmed by a decrease of the standard deviation.
In summary, ship emissions of aerosols and their precursors result in an increase of the droplet number concentration and a decrease in the effective radius in the cloud. A larger number of smaller droplets for a fixed liquid water content results in the observed increase in the cloud optical thickness. The results from satellite data analysis agree with previous studies, e.g. from the MAST-experiment (Öström et al., 2000; Hobbs et al., 2000; Ferek et al., 2000). 
A)

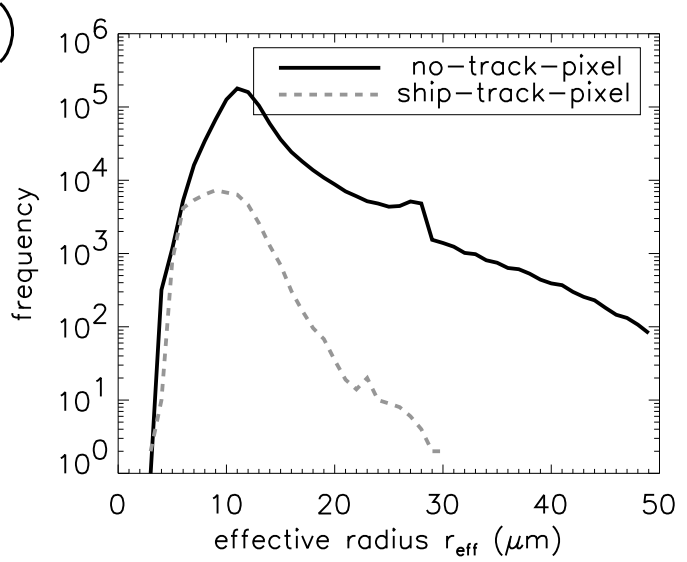

B)

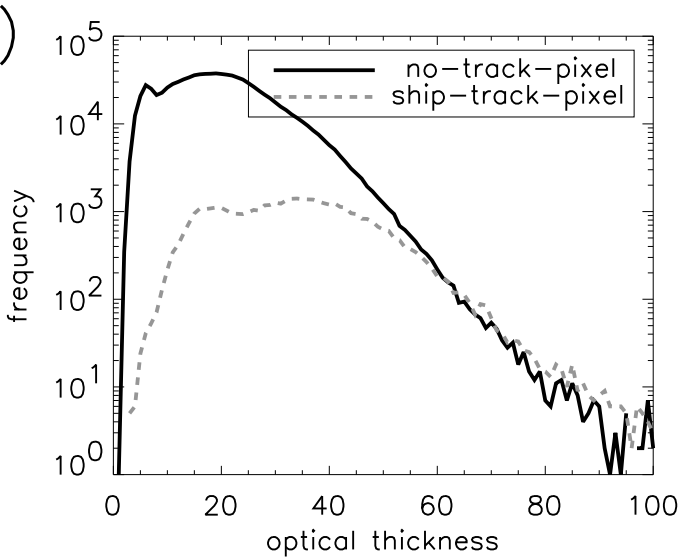

C)

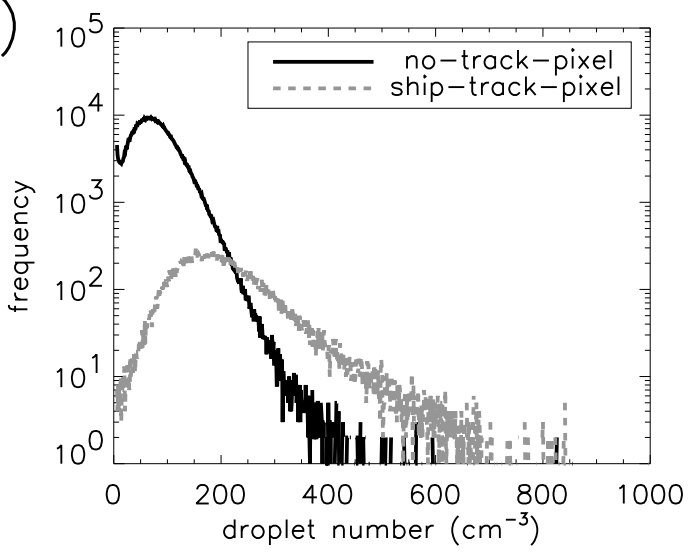

a)

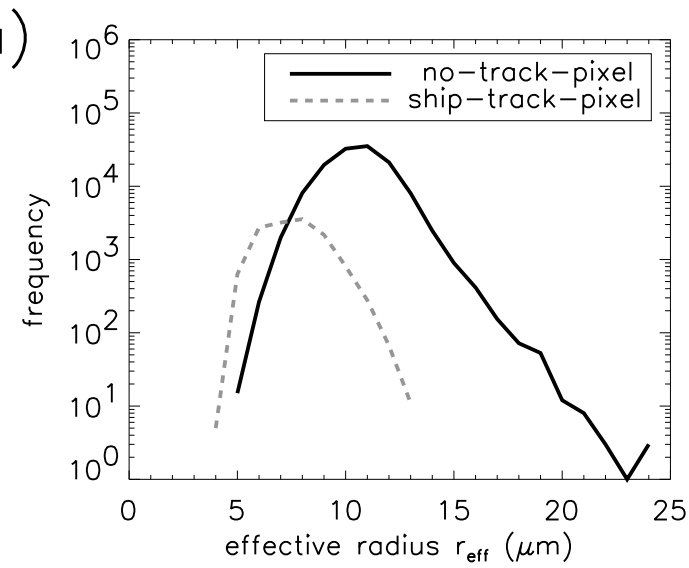

b)

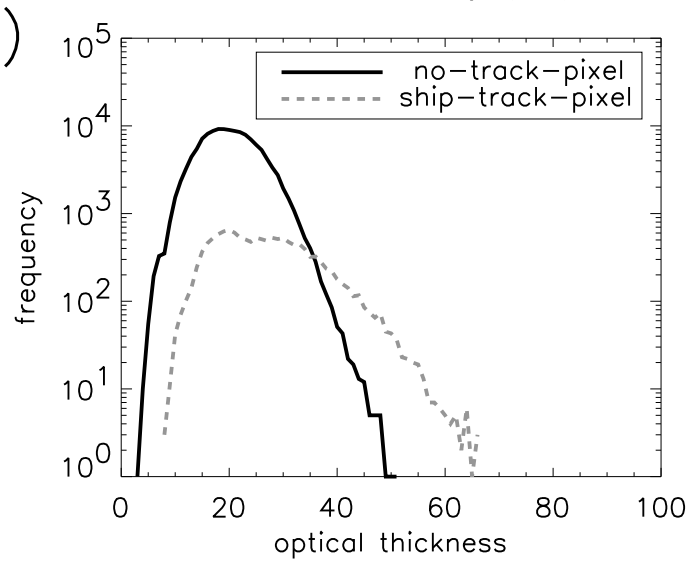

c)

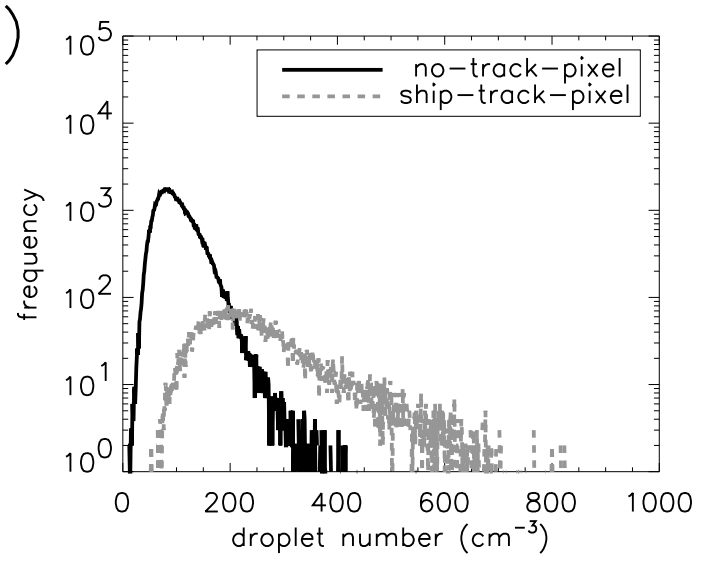

Fig. 11. Statistical distributions of the parameters for the no-track-pixel and the ship-track pixel for the entire scene (capital letters) and the smaller selected scene (lowercase letters):

(A, a) effective radius, (B, b) cloud optical thickness, (C, c) droplet number concentration.

\subsection{Radiative changes at surface and TOA}

\subsubsection{Radiative effects}

Figure 12 shows down-welling solar radiation at the surface below the clouds and reflected solar radiation at TOA, calculated by the method described in Sect. 3.4. In this calculation the optical parameters derived as described in Sect. 3.3. and depicted in Fig. 9, as well as the local solar zenith angle is taken into account for each pixel. As the local solar zenith angle varies over the scene from approx. $50^{\circ}$ to $80^{\circ}$, the simulated surface and TOA irradiance are influenced by both, the SZA and the optical parameters. Below a ship track the solar radiation is significantly reduced compared to outside the track because the reflectance of the cloud in the track is higher. The reflected solar radiation at TOA above the ship 

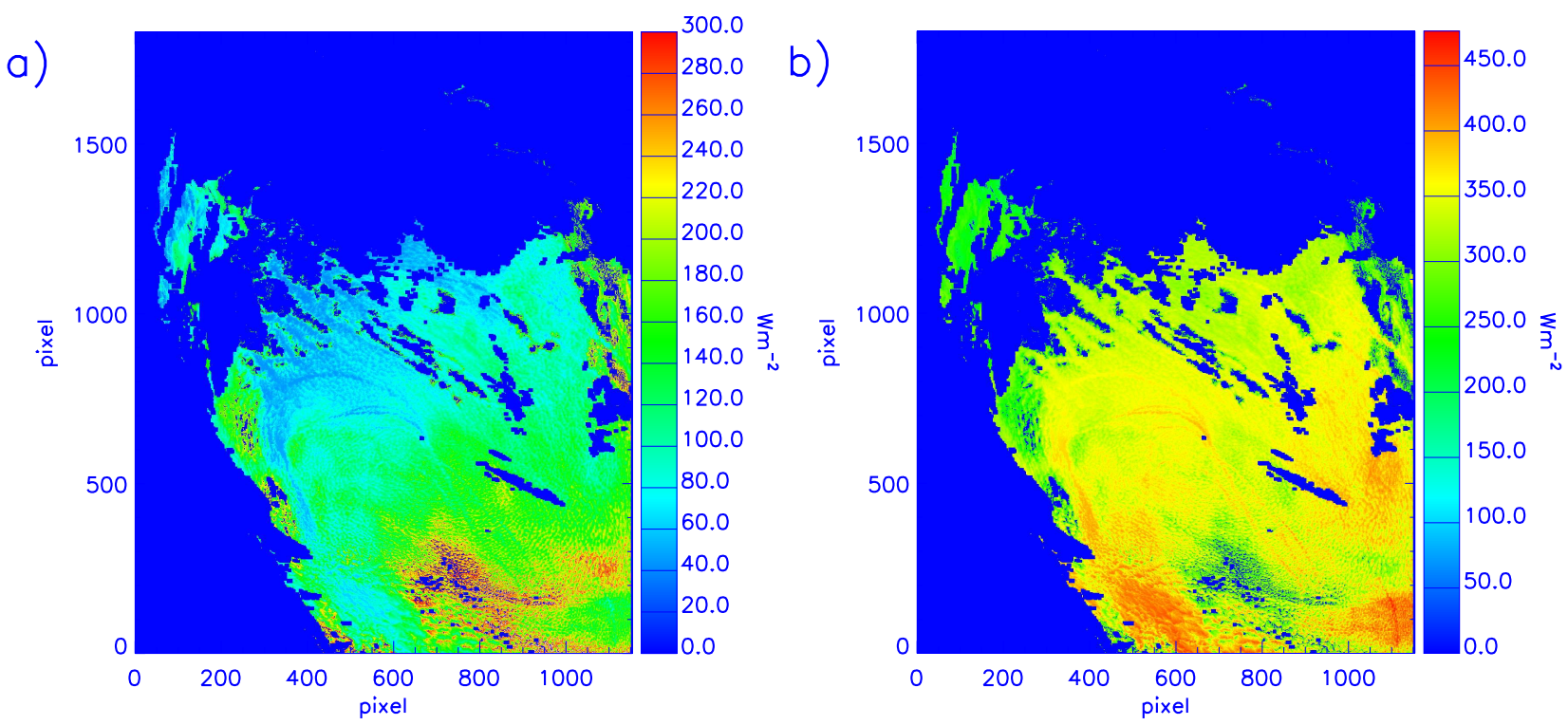

Fig. 12. Down-welling solar radiation at the surface below the clouds $\left(\mathbf{a}, \mathrm{in} \mathrm{Wm}^{-2}\right)$ and (b) reflected solar radiation on TOA due to the clouds $\left(b\right.$, in $\left.\mathrm{Wm}^{-2}\right)$.

Table 5a. Mean values of solar radiation at the surface and TOA for a fixed solar zenith angle of $63^{\circ}$, standard deviation in parenthesis.

\begin{tabular}{|c|c|c|c|c|}
\hline fixed sza $=63^{\circ}$ & $\begin{array}{l}\text { low-cloud-pixels } \\
\mathrm{E}_{\text {low-cloud }}\end{array}$ & $\begin{array}{l}\text { no-ship-track-pixels } \\
\mathrm{E}_{\text {no-ship-track }}\end{array}$ & $\begin{array}{l}\text { ship-track-pixels } \\
\text { E }_{\text {ship-track }}\end{array}$ & $\begin{array}{c}\text { difference } \\
\mathrm{E}_{\text {low-cloud }}-\mathrm{E}_{\text {no-ship-track }}\end{array}$ \\
\hline \multicolumn{5}{|l|}{ All low-cloud-pixel } \\
\hline Surface $\left(\mathrm{Wm}^{-2}\right)$ & $124.2(45.0)$ & $126.3(44.8)$ & $83.1(28.9)$ & -2.1 \\
\hline TOA $\left(\mathrm{Wm}^{-2}\right)$ & $332.1(38.2)$ & $330.1(37.8)$ & $370.9(23.5)$ & 2.0 \\
\hline \multicolumn{5}{|c|}{ Smaller selected scene } \\
\hline Surface $\left(\mathrm{Wm}^{-2}\right)$ & $113.5(44.1)$ & $115.5(44.2)$ & $93.6(27.9)$ & -2.0 \\
\hline TOA $\left(\mathrm{Wm}^{-2}\right)$ & $343.5(37.4)$ & $341.3(37.3)$ & $364.9(22.8)$ & 2.2 \\
\hline
\end{tabular}

tracks is significantly enhanced. Table 4 shows the mean values of the down-welling solar radiation at the surface and the reflected solar radiation at TOA, averaged over all ship-trackpixels ( $\left.E_{\text {ship-track }}\right)$, no-ship-track-pixels $\left(E_{\text {no-ship-track }}\right)$, and low-cloud-pixels ( $\left.E_{\text {low-clouds }}\right)$ for the whole scene and the smaller selected area. The resulting transmitted energy below the ship-track-pixels is reduced by 2.1 and $2.5 \mathrm{Wm}^{-2}$, for the smaller selected area and the entire scene respectively. The corresponding changes at TOA are an enhancement of the reflected solar radiation by $1.6 \mathrm{Wm}^{-2}$ for the smaller selected area and $0.9 \mathrm{Wm}^{-2}$ for all low-cloud-pixels.

When absolute radiation values (ship-track-pixels vs. noship-track-pixels) are compared, caution is required since the incident solar radiation at TOA depends on geographic position (i.e. on solar zenith angle) and ship tracks are not uniformly distributed over the selected scene. To quantify the magnitude of the solar zenith angle impact on the so- lar flux, the variation of the average incoming irradiance at TOA was simulated with the radiative transfer model for all pixels, all ship-track- and all no-ship-track-pixels for both, the full scene and the smaller selected area. The difference between all low cloud pixels and the no-ship-track-pixels is about $-0.6 \mathrm{Wm}^{-2}$ (all low-cloud-pixel) to $-1.6 \mathrm{Wm}^{-2}$ (smaller selected area). In addition to that, the cloud reflectance, transmittance as well as atmospheric absorption also depend on solar zenith angles. In summary, the impact of the solar zenith angle variation over the scene is of similar order of magnitude as the combined effect of changes in optical properties and solar zenith angle effects.

To separate the impact of changes in cloud parameters from ship tracks on the radiation field without the uncertainties represented by the solar zenith angle variations, radiative transfer calculations were performed assuming a mean solar zenith angle of $63^{\circ}$ (Table 5a) for all pixels. The calculated 
Table 5b. Same as Table 5a, but for a solar zenith angle of $50^{\circ}$.

\begin{tabular}{lcccc}
\hline fixed sza=50 & $\begin{array}{c}\text { low-cloud-pixels } \\
\mathrm{E}_{\text {low-cloud }}\end{array}$ & $\begin{array}{c}\text { no-ship-track-pixels } \\
\mathrm{E}_{\text {no-ship-track }}\end{array}$ & $\begin{array}{c}\text { ship-track-pixels } \\
\mathrm{E}_{\text {ship-track }}\end{array}$ & $\begin{array}{c}\text { difference } \\
\mathrm{E}_{\text {low-cloud }}-\mathrm{E}_{\text {no-ship-track }}\end{array}$ \\
\hline $\begin{array}{l}\text { All low-cloud-pixel } \\
\text { Surface }\left(\mathrm{Wm}^{-2}\right)\end{array}$ & $213.9(77.7)$ & $217.5(77.3)$ & $142.7(49.8)$ & -3.6 \\
TOA $\left(\mathrm{Wm}^{-2}\right)$ & $442.4(65.2)$ & $439.0(64.6)$ & $508.1(40.0)$ & 3.4 \\
\multicolumn{2}{l}{ Smaller selected scene } & & & -3.5 \\
Surface $\left(\mathrm{Wm}^{-2}\right)$ & $195.3(76.2)$ & $198.9(76.3)$ & $160.9(48.1)$ & 3.7 \\
TOA $\left(\mathrm{Wm}^{-2}\right)$ & $461.4(64.0)$ & $457.7(63.8)$ & $497.5(39.1)$ & \\
\hline
\end{tabular}

Table 5c. Same as Table 5a, but for a solar zenith angle of $70^{\circ}$.

\begin{tabular}{lcccc}
\hline fixed sza $=70^{\circ}$ & $\begin{array}{c}\text { low-cloud-pixels } \\
E_{\text {low-cloud }}\end{array}$ & $\begin{array}{c}\text { no-ship-track-pixels } \\
\mathrm{E}_{\text {no-ship-track }}\end{array}$ & $\begin{array}{c}\text { ship-track-pixels } \\
\mathrm{E}_{\text {ship-track }}\end{array}$ & $\begin{array}{c}\text { difference } \\
\mathrm{E}_{\text {low-cloud }}-\mathrm{E}_{\text {no-ship-track }}\end{array}$ \\
\hline $\begin{array}{l}\text { All low-cloud-pixel } \\
\text { Surface }\left(\mathrm{Wm}^{-2}\right)\end{array}$ & $80.6(29.1)$ & $82.0(28.9)$ & $54.0(18.7)$ & -1.4 \\
TOA $\left(\mathrm{Wm}^{-2}\right)$ & $258.6(24.8)$ & $257.3(24.6)$ & $284.0(18.1)$ & 1.3 \\
$\begin{array}{l}\text { Smaller selected scene } \\
\text { Surface }\left(\mathrm{Wm}^{-2}\right)\end{array}$ & $73.8(28.5)$ & $75.1(28.6)$ & $60.9(18.1)$ & -1.3 \\
TOA $\left(\mathrm{Wm}^{-2}\right)$ & $266.1(24.4)$ & $264.7(24.3)$ & $280.3(14.8)$ & 1.4 \\
\hline
\end{tabular}

values in Table 5 now only depend on the cloud optical properties, as the influence of a varying solar zenith angle has been eliminated.

Assuming a constant solar zenith angle, the mean value of the down-welling solar radiation at the surface below the ship-track-pixels is reduced by $43.2 \mathrm{Wm}^{-2}$ due to the change in the cloud parameters, compared to the no-ship-track-pixels in the entire scene. This change is comparable to the calculated discrepancy of $63 \mathrm{Wm}^{-2}$ between maritime and continental clouds as proposed by Kiehl (1994) for a similar solar zenith angle. At TOA, ship-track-pixels reflect $40.8 \mathrm{Wm}^{-2}$ more than the no-ship-track-pixels for the entire scene. For the selected area the reduction of the down-welling solar radiation at the surface due to ship tracks is $22.1 \mathrm{Wm}^{-2}$ and the increase in TOA is $23.6 \mathrm{Wm}^{-2}$.

The net radiative effect of the change in cloud properties due to ships for the particular scene is estimated by calculating the difference of the absolute radiation values between all low-cloud-pixels ( $\mathrm{E}_{\mathrm{low}-\text { cloud }}$ ) and the no-ship-track-pixels $\left(E_{n o-s h i p-t r a c k}\right)$. According to these values, the solar radiation at the surface is reduced on average by $2.1 \mathrm{Wm}^{-2}$ by the ship emissions and additional $2.0 \mathrm{Wm}^{-2}$ are reflected back at TOA. Table 5a also shows the values for the smaller selected area with an on average decrease in the radiation of $2.0 \mathrm{Wm}^{-2}$ at the surface and an increase in the outgoing radiation at TOA of $2.2 \mathrm{Wm}^{-2}$ due to the ship emissions.
For the same spatial distribution of cloud and ship track properties, the solar radiation has been also calculated for other solar zenith angles to get an estimate of the dependence of the radiation changes by ship tracks on the solar zenith angle (Tables 5b-d). For a smaller solar zenith angle of $50^{\circ}$ the scene average radiation decreases to $-3.6 \mathrm{Wm}^{-2}$ at the surface and increases to $3.4 \mathrm{Wm}^{-2}$ at TOA. For larger mean solar zenith angle of $70^{\circ}$ the scene average change is $-1.4 \mathrm{Wm}^{-2}$ at the surface and $1.3 \mathrm{Wm}^{-2}$ for the backscattered radiation at TOA. For an even large solar zenith angle of $80^{\circ}$ the change is only $-0.5 \mathrm{Wm}^{-2}$ for the surface and only $0.5 \mathrm{Wm}^{-2}$ for TOA. In summary, smaller SZA result in an amplification of the solar radiation changes on the surface and TOA, whereas for high solar zenith angles the effect will vanish. Ship tracks can have al long lifetime, e.g. Durkee et al. (2000b) give an average estimate of $7.5 \mathrm{~h}$ but they also report a high variability. Therefore, the solar zenith angle variation has to be included when estimating the radiative impact of ship tracks. A possible change in thermal radiation was also analysed taking into account the changes in cloud optical properties and also changes in cloud top height. A small reduction of $0.7 \mathrm{Wm}^{-2}$ at TOA was found by comparison of non-ship-track-pixels and ship-track-pixels. This results in a negligible change of less then $0.1 \mathrm{Wm}^{-2}$ for the entire scene. The results are similar for the smaller selected scene. 
Table 5d. Same as Table 5a, but for a solar zenith angle of $80^{\circ}$.

\begin{tabular}{lcccc}
\hline fixed sza=80 & $\begin{array}{c}\text { low-cloud-pixels } \\
\mathrm{E}_{\text {low-cloud }}\end{array}$ & $\begin{array}{c}\text { no-ship-track-pixels } \\
\mathrm{E}_{\text {no-ship-track }}\end{array}$ & $\begin{array}{c}\text { ship-track-pixels } \\
\mathrm{E}_{\text {ship-track }}\end{array}$ & $\begin{array}{c}\text { difference } \\
\mathrm{E}_{\text {low-cloud }}-\mathrm{E}_{\text {no-ship-track }}\end{array}$ \\
\hline $\begin{array}{l}\text { All low-cloud-pixel } \\
\text { Surface }\left(\mathrm{Wm}^{-2}\right)\end{array}$ & $30.4(10.9)$ & $30.9(10.8)$ & $20.4(7.1)$ & -0.5 \\
TOA $\left(\mathrm{Wm}^{-2}\right)$ & $134.6(9.4)$ & $134.1(9.3)$ & $144.3(5.8)$ & 0.5 \\
\multicolumn{2}{l}{ Smaller selected scene } & & & \\
Surface $\left(\mathrm{Wm}^{-2}\right)$ & $27.9(10.7)$ & $28.4(10.7)$ & $23.0(6.8)$ & -0.5 \\
TOA $\left(\mathrm{Wm}^{-2}\right)$ & $137.5(9.2)$ & $136.9(9.2)$ & $142.9(5.6)$ & 0.6 \\
\hline
\end{tabular}

The results show that anthropogenic emissions from ships influence maritime clouds and affect the radiative energy budget at the surface and also the reflected radiation at TOA. Ship tracks show an increased reflection of solar radiation compared to unaffected clouds. For the scene investigated in this work, the net-effect is a reduction by 1 to $3 \mathrm{Wm}^{-2}$, depending on how the solar zenith angle impact is estimated.

Not included in this analysis is the diurnal cycle of maritime stratiform clouds (Cahalan et al., 1994; Norris, 1998b) and the lifetime of ship tracks, also influencing the radiative behaviour.

\subsection{Impact of cloud mask parameters on radiation values}

In addition to the sensitivity of the cloud mask parameters on the number of detected ship-track-pixels (Sect. 4.1.) and microphysical properties (Sect. 4.2.), here we estimate the sensitivity of the cloud mask parameters on changes in radiation.

As can be seen in Fig. 11, the cloud optical parameters are not equally distributed which results in a non-linear correlation of the resulting loss or augmentation of pixel as described in Table 1. Table 6 shows the sensitivity of the resulting loss of radiation at TOA. Changing the parameters of the Canny-edge-filtering by $10 \%$ results in relatively small changes in the radiation. But for a variation by $50 \%$, results change significantly. The edge filtering picks up only the most reflective pixel and the reduced pixel amount of $2.2 \%$ is only the highly radiative ship-track-pixel, corresponding to a value of $7.5 \mathrm{Wm}^{-2}$. On the other side, the increased detection of $31.5 \%$ can be explained by a higher detection of previously no-ship-track-pixels as ship-track-pixels resulting in a decrease of $0.7 \mathrm{Wm}^{-2}$. Therefore, a high amount of shiptrack-pixels is required for such calculations. For only $2.2 \%$ of the ship-track-pixel of the entire scene, the calculation of the net effect of the scene would increase the estimation of the net effect by $5.5 \mathrm{Wm}^{-2}$. For the remaining factors of the algorithm, variation works vice versa: a reduction of the detected pixel results in a reduction of the radiation value. In this case, the edge filtering did already pick up the radiatively relevant pixels. The remaining factors can only reduce the mean value by reducing the pixel amount. For these factors, the value has only an important change, if the width of the ship track is reduced or increased by $50 \%$.

In conclusion, the cloud mask algorithm extracts the most radiatively relevant ship-track pixel via the edge filtering.

\section{Summary and conclusion}

An algorithm has been developed to determine ship tracks from satellite data in an automated way. A scene on 10 February 2003 was chosen to extract the optical and microphysical cloud modifications from ship emissions using Terra-MODIS satellite data. A combination of the semianalytical approach SACURA with a look-up-table for optically thin clouds was used to calculate cloud properties.

It was demonstrated that the wake of a ship might influence the ship track detection if changes of the surface would reach pixel size. Adding a channel in the near infrared helps to exclude errors by foam.

It has also been shown that ship emissions modify existing clouds by decreasing the effective radius, while they increase droplet concentration and optical thickness. On average, the optical thickness was increased from 20.7 up to 34.6 and the effective radius was decreased from $13.2 \mu \mathrm{m}$ to $10.1 \mu \mathrm{m}$. The calculated average droplet number concentration increased from 79 up to $210 \mathrm{~cm}^{-3}$. The results agree with mean values calculated by MODIS standard cloud product and also with the theory and experiment (Öström et al., 2000; Hobbs et al., 2000): Low clouds of the maritime boundary layer have less cloud condensation nuclei than clouds over land; in consequence, this results in larger droplet radii for similar water content and dispersion of droplet size distributions. Injection of aerosols and their precursors by ships results in more $\mathrm{CCNs}$ causing the mean droplet radius to decrease and the droplet number concentration to increase.

The derived parameters were used to calculate changes in the radiative energy budget below and above the cloud. The mean values show a decrease of $43.2 \mathrm{Wm}^{-2}$ for the surface 
Table 6. Change of results for entire scene, if variation of the cloud mask parameters is done as in Table 1.

\begin{tabular}{lcc}
\hline & Change of parameter $(\%)$ & backscattered Radiation $\left(\mathrm{Wm}^{-2}\right)$ \\
\hline Canny-Edge Parameter & $-10 / 10$ & $2.4 / 1.6$ \\
& $-50 / 50$ & $7.5 / 0.7$ \\
Width of ship track & $-10 / 10$ & $1.8 / 2.1$ \\
& $-50 / 50$ & $1.1 / 2.4$ \\
Ratio inside/outside-pixel & $-10 / 10$ & $1.9 / 2.0$ \\
& $-50 / 50$ & $1.7 / 2.1$ \\
Ratio of length/width & $-10 / 10$ & $1.9 / 2.0$ \\
& $-50 / 50$ & $1.8 / 2.1$ \\
\hline
\end{tabular}

radiation below ship tracks and an increase of $40.8 \mathrm{Wm}^{-2}$ for the increased reflectivity at TOA. If the whole low-cloud area with $6.7 \%$ ship-track-pixels is taken into account, a decrease in the radiation at the surface of $2.1 \mathrm{Wm}^{-2}$ and an increase of $2.0 \mathrm{Wm}^{-2}$ in backscattered solar radiation was found, when assuming a constant solar zenith angle of $63^{\circ}$ for the scene. A small reduction of thermal radiation was found at TOA with almost no effect for the entire scene.

Changes in radiation have also been calculated for a smaller area of the selected scene. The results show similar changes, supporting the radiation effects calculated for the entire scene: a decreased radiation at the surface of $2.0 \mathrm{Wm}^{-2}$, an increased backscattered radiation of $2.2 \mathrm{Wm}^{-2}$.

The results showed that modifications of clouds by international shipping can be an important contributor to climate on a local scale. Further studies are needed to assess the global impact of ship-track formation on climate.

Acknowledgements. We wish to thank the MODIS NASA team for providing the MODIS data products in such a straightforward way on their website. Special thanks go to A. Lauer, T. Zinner and U. Schumann (DLR) for helpful discussions. This work has been supported by the Helmholtz-University Young Investigators Group SeaKLIM, which is funded by the German HelmholtzGemeinschaft, and the Deutsches Zentrum für Luft- und Raumfahrt e.V. (DLR). We also acknowledge support of the DFG project BU 688/8-1.

We would like to thank the anonymous reviewers for the careful reading of the manuscript and resulting criticisms.

Edited by: G. Feingold

\section{References}

Ackermann, A. S., Toon, O. B., Taylor, J. P., Johnson, D. W., Hobbs, P. V., and Ferek, R. J.: Effects of aerosols on cloud albedo: Evaluation of Twomey's parameterisation of cloud susceptibility using measurements of ship tracks, J. Atmos. Sci., 57, 2684-2695, 2000 .
Anderson, G. P., Clough, S. A., Kneizys, F. X., Chetwynd, J. H., and Shettle, E. P.: AFGL Atmospheric Constituent Profiles (0$120 \mathrm{~km}$ ), AFGL-TR-86-0110, AFGL (OPI), Hanscom AFB, MA 01736, 1986.

Beirle, S., Platt, U., von Glasow, R., Wenig, M., and Wagner, T.: Estimate of nitrogen oxide emissions from shipping by satellite remote sensing, Geophys. Res. Lett., 31, L18102, doi:10.1029/2004GL020312, 2004.

Christopher, S. A. and Zhan, J.: Shortwave aerosol radiative forcing from MODIS and CERES observations over the oceans, Geophys. Res. Lett., 29, 1859-1865, 2002.

Cahalan, R. F., Ridgway, W., Wiscombe, W. J., Bell, T. J., and Snider, J. B.: The albedo of fractal stratocumulus clouds, J. Atmos. Sci., 51, 2434-2455, 1994.

Capaldo, K., Corbett, J. J., Kasibhatla, P., Fischbeck, P. S., and Pandis, S. N.: Effects of ship emissions on sulphur cycling and radiative climate forcing over the ocean, Nature, 400, 743-746, 1999.

Coakley, J. A., Bernstein, R. L., and Durkee, P. A.: Effect of shipstack effluents on cloud reflectivity, Science, 237, 1020-1022.

Coakley Jr., J. A., Durkee, P. A., Nielsen, K., Taylor, J. P., Platnick, S., Albrecht, B. A., Babb, D., Chang, F. L., Tahnk, W. R., Bretherton, C. S., and Hobbs, P. V.: The appearance and disappearance of ship tracks an large spatial Scales, J. Atmos. Sci., 57, 2765-2778, 2000.

Coakley Jr., J. A. and Walsh, C. D.: Limits to the indirect aerosol effect derived from observations of ship tracks, J. Atmos. Sci., 59, 668-680, 2002.

Conover, J. H.: Anomalous cloud lines, J. Atmos. Sci., 23, 778785, 1966.

Cox, C. and Munk, W.: Statistics of the sea surface derived from sun glitter, J. Marine Res., 13, 198-227, 1954.

Davis, D. D., Grodzinsky, G., Kasibhatla, P., Crawford, J., Chen, G., Liu, S., Bandy, A., Thornton, D., Guan, H., and Sandholm, S.: Impact of ship emissions on marine boundary layer $\mathrm{NO}_{\mathrm{x}}$ and $\mathrm{SO}_{2}$ distributions over the Pacific Basin, Geophys. Res. Lett., 28, 235-238, 2001.

Deirmendjian, A.: Electromagnetic scattering on spherical polydispersions, Elsevier, Amsterdam, 1969.

Durkee, P. A., Noone, K. J., and Bluth, R. T.: The Monterey Ship Track Experiment, J. Atmos. Sci., 57, 2523-2541, 2000a.

Durkee, P. A., Chartier, R. E., Brown, A., Trehubenko, E. J., Rogerson, S. D., Skupniewicz, C., Nielsen, K. E., Platnick, S., and King, M. D.: Composite ship track characteristics, J. Atmos. Sci., 57, 2542-2553, 2000 b. 
Durkee, P. A., Noone, K. J., Ferek, R. J., Johnson, D. W., Taylor, J. P., Garrett, T. J., Hobbs, P. V., Hudson, J. G., Bretherton, C. S., Innis, G., Frick, G. M., Hoppel, W. A., O’Dowd, C. D., Russel, L. M., Gasparovic, R., Nielsen, K. E., Tessmer, S. A., Öström, E., Osbourne, S. R., Flagan, R. C., Seinfeld, J. H., and Rand, H.: The impact of ship-produced aerosols on the microstructure and albedo of warm marine stratocumulus clouds: A test of MAST hypothesis 1i and 1ii, J. Atmos. Sci., 57, 2554-2569, 2000c.

Endresen, O., Sorgard, E., Sundet, J. K., Dalsoren, S. B., Isaksen, I. S. A., Berglen, T. F., and Gravir, G.: Emission from international sea transportation and environmental impact, J. Geophys. Res., 108, 4560, doi:10.1029/2002JD00JD002898, 2003.

Entec UK Limited: European Commission: Quantification of emissions from ships associated with ship movements between ports in the European Community, Final Report, July 2002, Entec UK Limited, 2002.

EPA: United States Environmental Protection Agency Air and Radiation, Analysis of commercial marine vessels emissions and fuel , EPA420-R-00-002, February 2000.

Eyring, V., Köhler, H. W., van Aardenne, J., and Lauer, A.: Emissions from international shipping: 1. The last 50 years, J. Geophys. Res., 110, D17305, doi:10.1029/2004JD005619, 2005a.

Eyring, V., Köhler, H. W., Lauer, A., and Lemper, B.: Emissions from international shipping: 2. Impact of future technologies on scenarios until 2050, J. Geophys. Res., 110, D17306, doi:10.1029/2004JD005620, 2005b.

Facchini, M. C., Mircea, M., Fuzzi, S., and Charlson, R. J.: Cloud albedo enhancement by surface-active organic solutes in growing droplets, Nature, 401, 257-259, 1999.

Ferek, R. J., Garrett, T., Hobbs, P. V., Strader, S., Johnson, D., Taylor, J. P., Nielsen, K., Ackermann, A. S., Kogan, Y., Liu, Q., Albrecht, B. A., and Babb, D.: Drizzle suppression in ship tracks, J. Atmos. Sci., 57, 2707-2728, 2000.

Frick, G. M. and Hoppel, W. A.: Airship measurements of ship's exhaust plumes and their effect on marine boundary layer clouds, J. Atmos. Sci., 57, 2625-2648, 2000.

$\mathrm{Fu}$, Q. and Liou, K. N.: On the correlated k-distribution method for radiative transfer in nonhomogeneous atmospheres, J. Atmos. Sci., 49, 2139-2156, 1992.

Han, Q., Rossow, W. B., Chou, J., and Welch, R. M.: Global variation of column droplet concentration in low-level clouds, Geophys. Res. Lett., 25(9), 1419-1422, 1998.

Hobbs, P. V., Garrett, T. J., Ferek, R. J., Strader, S. R., Hegg, D. A., Frick, G. M., Hoppel, W. A., Gasparovic, R. F., Russell, L. M., Johnson, D. W., O’Dowd, C., Durkee, P. A., Nielsen, K. E., and Innis, G.: Emissions from ships with their respect to clouds, J. Atmos. Sci., 57, 2570-2590, 2000.

Hooper, W. P. and James, E. J.: Lidar observations of ship plumes, J. Atmos. Sci., 57, 2649-2566, 2000.

Hudson, J. G., Garrett, T. J., Hobbs, P. V., Strader, S. R., Xie, Y., and Yum, S. S.: Cloud condensation nuclei and ship tracks, J. Atmos. Sci., 57, 2696-2707, 2000.

Jin, Z., Charlock, T. P., and Rutledge, K.: Analysis of broadband solar radiation and albedo over the ocean surface at COVE, J. Atmos. Ocean. Technol., 19, 1585-1601, 2002.

Johnson, W. D., Osborne, S., Wood, R., Suhre, K., Quinn, P. K., Bates, T., Andreae, M. O., Noone, K. J., Glantz, P., Bandy, B., Rudolph, J., and O'Dowd, C.: Observations of the evolution of the aerosol, cloud and boundary-layer characteristics during the 1st ACE-2 Lagrangian experiment, Tellus, 52B, 348-374, 2000.

Kasibhatla, P., Levy II, H., Moxim, W. J., Pandis, S. N., Corbett, J. J., Peterson, M. C., Honrath, R. E., Frost, G. J., Knapp, K., Parrish, D. D., and Ryerson, T. B.: Do emissions form ships have a significant impact on concentration of nitrogen oxides in the marine boundary layer?, Geophys. Res. Lett., 27(15), 2229 2233, 2000.

Kato, S., Ackermann, T. P., Mather, J. H., and Clothiaux, E. E. The k-distribution method and correlated-k approximation for a shortwave radiative transfer model, J. Quant. Spectrosc. Radiat. Trans., 62, 109-121, 1999.

Kiehl, J. T.: Sensitivity of GCM climate simulation to differences in continental versus maritime cloud droplet size, J. Geophys. Res., 99, 23 107-23 115, 1994.

King, M. D., Herring, D. D., and Diner, D. J.: The Earth Observing System (EOS): A space based program for asessing mankind's impact on the global environment, Opt. Photon News, 6, 34-39, 1995.

King, M. D., Menzel, W. P., Kaufman, Y. J., Tanré, D., Gao, B.C., Platnick, S., Ackerman, S. A., Remer, L. A., Pincus, R., and Hubanks, P. A.: Cloud and aerosol properties, precipitable water, and profiles of temperature and water vapor from MODIS, IEEE Trans. Geosci. Remote Sensing, 41, 442-458, 2003.

Kokhanovsky, A. A., Rozanov, V. V., Zege, E. P., Bovensmann, H., and Burrows, J. P.: A semi-analytical cloud retrieval algorithm using backscattered radiation in $0.4-2.4 \mathrm{mi}-$ crometers spectral range, J. Geophys. Res., 108(D1), 4008, doi:10.1029/2001JD001543, 2003.

Kokhanovsky, A. A.: Optical properties of terrestrial clouds, Earth Sci. Rev., 64, 189-241, 2004a.

Kokhanovsky, A. A.: Spectral reflectance of whitecaps, J. Geophys. Res., 109, C05021, doi:10.1029/2003JC002177, 2004b.

Lawrence, M. G. and Crutzen, P. J.: Influence of $\mathrm{NO}_{\mathrm{x}}$ emissions from ships on tropospheric photochemistry and climate, Nature, 402, 167-170, 1999.

Lensky, I. M. and Rosenfeld, D.: Satellite-based insights into preciptitation formation processes in continental and maritime convective clouds at nighttime, J. Appl. Meteorol., 42, 1227-1233, 2003.

Liu, Q., Kogan, Y. L., Lilly, D. K., Johnson, D. W., Innis, G. E., Durkee, P. A., and Nielsen, K. E.: Modelling of effluent transport and its sensitivity to boundary layer structure, J. Atmos. Sci., 57, 2779-2791, 2000.

Lohmann, U.: Possible aerosol effects on ice clouds via contact nucleation, J. Atmos. Sci., 59, 647-656, 2002.

Masunaga, H., Nakajima, T. Y., Nakajima, T., Kachi, M., and Suzuki, K.: Physical properties of maritime low clouds as retrieved by combined use of Tropical Rainfall Measuring Mission (TRMM) Microwave Imager and Visible/Infrared Scanner 2. Climatology of warm clouds and rain, J. Geophys. Res., 107, 4367, doi:10.1029/2001JD1269, 2002.

Mayer, B., Seckmeyer, G., and Kylling, A.: Systematic longterm comparison of spectral UV measurements and UVSPEC modeling results (libRadtran-Homepage: http://www.libRadtran.org), J. Geophys. Res., 102(D7), 8755-8768, 1997.

Mayer, B. and Kylling, A.: Technical note: The libRadtran software package for radiative transfer calculations, description and examples of use, Atmos. Chem. Phys., 5, 1855-1877, 2005, http://www.atmos-chem-phys.net/5/1855/2005/. 
McInnes, L. M., Quinn, P. K., Covert, D. S., and Anderson, T. L.: Gravimetric analysis, ionic composition and associated water mass of the marine Aerosol, Atmos. Environ., 30, 869-884, 1996.

Miles, N. L., Verlinde, J., and Clothiaux, E. E.: Cloud droplet size distributions in low-level stratiform clouds, J. Atmos. Sci., 57, 295-311, 2000.

Nakajima, T. and Tanaka, M.: Effect of wind-generated waves on the transfer of solar radiation in the atmosphere-ocean system, J. Quant. Spectrosc. Radiat. Trans., 29, 521-537, 1983.

Nauss, T., Kokhanovsky, A. A., Nakajima, T. Y., Reudenbach, C., and Bendix, J.: The intercomparison of selected cloud retrieval algorithms, Atmos. Res., 78, 46-78, 2005.

Noone, K. J., Öström, E., Ferek, R. J., Garrett, T., Hobbs, P. V., Johnson, D. W., Taylor, J. P., Russell, L. M., Fragan, R. C., Seinfeld, J. H., O’Dowd, C. D., Smith, M. H., Durkee, P. A., Nielsen, K., Hudson, J. G., Pockalny, R. A., de Bock, L., van Grieken, R. E., Gasparovic, R. F., and Brooks, I.: A case study of ships Forming and not forming tracks in moderately polluted clouds, J. Atmos. Sci., 57, 2729-2747, 2000a.

Noone, K. J., Johnson, D. W., Taylor, J. P., Ferek, R. J., Garrett, T., Hobbs, P. V., Durkee, P. A., Nielsen, K., Öström, E., O’Dowd, C., de Bock, L., van Grieken, R. E., Hudson, J. G., Brooks, I., Gasparovic, R. F., and Pockalny, R. A.: A case study of ship track formation in polluted marine boundary layer, J. Atmos. Sci., 57, 2748-2764, 2000b.

Norris, J. R.: Low cloud type over the ocean from surface observations. Part I: Relationship to surface meteorology and the vertical distribution of temperature and moisture, J. Climate, 11(3), 369382, 1998a.

Norris, J. R.: Low cloud type over the ocean from surface observations. Part II: geographical and seasonal variations, J. Climate, 11(3), 383-403, 1998b.

O’Dowd, C. D., Smith, M. H., Consterdine, I. E., and Lowe, J. A.: Marine aerosol, sea-salt and the marine sulphur cycle: A short review, Atmos. Environ., 31, 73-80, 1997.

O’Dowd, C. D., Facchini, M. C., Cavalli, F., Ceburnis, D., Mircea, M., Decesari, S., Fuzzi, S., Yoon, Y. J., and Putaud, J. P.: Biogenically-driven organic contribution to marine aerosol, Nature, 431, 676-680, doi:10.1038/nature02959, 2004.

Öström, E., Noone, K. J., and Pockalny, R. A.: Cloud droplet residual particle microphysics in marine stratocumulus clouds observed during the Monterey Area Ship Track Experiment, J. Atmos. Sci., 57, 2671-2683, 2000.
Platnick, S., King, M. D., Ackerman, S. A., Menzel, W. P., Baum, B. A., Riedi, J. C., and Frey, R. A.: The MODIS cloud products: Algorithms and examples from Terra, IEEE Trans. Geosci. Remote Sensing, 41, 459-473, 2003.

Porch, W. M., Kao, C. Y., Buckwald, M. I., Unruh, W. P., Durkee, P. A., Hindman, E. E., and Hudson, J. G.: The effects of external forcing on the marine boundary layer: Ship trails and a solar eclipse, Global Atmos. Ocean System, 3, 323-340, 1995.

Radke, L. F., Coakley Jr., J. A., and King, M. D.: Direct and remote Sensing observations of the effects of ships on clouds, Science, 346, 1146-1149, 1989.

Richter, A., Eyring, V., Burrows, J. P., Bovensmann, H., Lauer, A., Sierk, B., and Crutzen, P. J.: Satellite measurements of NO2 from internal shipping emissions, Geophys. Res. Lett., 31, L23110, doi:10.1029/2004GL020822, 2004.

Rosenfeld, D. and Gutman, G.: Retrieving microphysical properties near the tops of potential rain clouds by multispectral analysis of AVHRR data, Atmos. Res., 34, 259-283, 1994.

Russel, L. M., Noone, K. J., Ferek, R. J., Pockalny, R. A., Flagan, R. C., and Seinfeld, J. H.: Combustion organic aerosol as cloud condensation nuclei in ship tracks, J. Atmos. Sci., 57, 2591-2606, 2000.

Seinfeld, J. H. and Pandis, S. N.: Atmospheric Chemistry and Physics, John Wiley and Sons, Inc., 1997.

Simmons, A. J. and Gibson, J. K. (Eds.): ERA-40 Project plan, ERA-20 Project Rep. 1, ECMWF, 62 p, 2000.

Stamnes, K., Tsay, S. C., Wiscombe, W., and Jayaweera, K.: Numerically stable algorithm for discrete-ordinate-method radiative transfer in multiple scatteringand emitting layered media, Appl. Opt., 27, 2502-2509, 1988.

Taylor, J. P., Glew, M. D., Coakley Jr., J. A., Tahnk, W. R., Platnick, S., Hobbs, P. V., and Ferek, R. J.: Effects of aerosols on the radiative properties of clouds, J. Atmos. Sci., 57, 2656-2670, 2000.

Twomey, S., Howell, H. B., and Wojciechowski, T. A.: Comments on anomalous cloud lines, J. Atmos. Sci., 25, 333-334, 1968.

Twomey, S.: Pollution and the planetary albedo, Atmos. Environ., 8, 1251-1256, 1974.

Wang, J., Rossow, W. B., and Zhang, Y.: Cloud vertical structure and its variation from a 20 -yr global rawinsonde dataset, J. Climate, 13, 3041-3056, 2000.

World Bunkering: Issue 9, Number 3, August, 2004. 